\title{
CURRENT LITERATURE ON ANIMAL BEHAVIOR AND PHYSIOLOGICAL PSYCHOLOGY
}

Citations of current literature are arranged in outline form so that readers may easily find the particular articles in which they are interested. The literature on Animal and Physiological Psychology is divided into two parts, with each part appearing in alternate moniths. The part covered here consists of Animal Behavior (exclusive of Animal Learning) and Physiological Psychology. The part to be published next month will consist of citations on Animal Learning. The principal headings used are given on the cover along with page references.

\section{ANIMAL BEHAVIOR}

\section{DEVELOPMENT Genetics}

HENDERSON, N. D. (Oberlin Coll., Oberlin, Ohio 44074). Relative effects of early rearing environment and genotype on discrimination learning in house mice. Journal of Comparative \& Physiological Psychology, 1972, 79, 243-253.

OLIVERIO, A. (Laboratorio di Psicobiologia e Psicofarmacologia, C . N . R ., R o m e, It a ly ), CASTELLANO, C., \& MESSERI, P. Genetic analysis of avoidance, maze, and wheel-running behaviors in the mouse. Journal of Comparative \& Physiological Psychology, 1972, 79, 459-473.

PARÉ, W. P. (VA Hosp., Perry Point, Md. 21902). Conflict duration, feeding schedule, and strain differences in conflict-induced gastric ulcers. Physiology \& Behavior, 1972, 8, 165-171.

PEELER, D. F., JR. (Dept. of Neurosurg., Univ. of Mississippi Med. Ctr., Jackson, Misś. 39216). Activity as a function of genetic variables and opportunity for exploration. Psychonomic Science, 1972, 27, 176-178.

RICHMAN, C. L. (Wake Forest Univ., Winston-Salem, N.C. 27109), GULKIN, R., \& KNOBLOCK, K. Effects of bulbectomization, strain, and gentling on emotionality and exploratory behavior in rats. Physiology \& Behavior, 1972, 8, 447-452.

ROSECRANS, J. A. (Dept. of P h a r m a c o l., Virginia Commonwealth Univ., Med. Coll. of Virginia, Richmond, Va. 23219), \& SCHECHTER, M. D. Brain 5-hydroxytryptamine correlates of behavior in rats: Strain and sex variability. Physiology \& Behavior, 1972, 8, 503-510.

VALE, J. R. (Univ. of California, Berkeley, Calif. 94720), RAY, D., \& VALE, C. A. The interaction of genotype and exogenous neonatal androgen: Agonistic behavior in female mice. Behavioral Biology, 1972, 7, 321-334.

WAHISTEN, D. (Univ. of Waterloo, Waterloo, Ont., Canada). Genetic experiments with animal learning: $A$ critical review. Behavioral Biology, 1972, 7, 143-182.

WILSON, D. M. (c/o Donald Kennedy, Dept. of Biol. Sci., Stanford Univ., Stanford, Calif. 94305). Genetic and sensory mechanisms for locomotion and orientation in animals. American Scientist, 1972, $60,358-365$.

\section{Early Experience}

BRAIN, P. F. (Dept. of Zool., Univ. Coll. of Swansea, Glamorganshire, Wales). Effects of isolation/grouping on endocrine function and fighting behavior in male and female golden hamsters (Mesocricetus auratus Waterhouse). Behavioral Biology, 1972, 7, 349-357.

DMITRUK, V. M. (Grant Valley State Coll., Allendale, Mich. 49401), \& ROOSSIEN, J. R. Emotionality of rats stimulated in infancy: Effects of intensity and predictability of shock. Psychological Reports, 1972 , $30,555-559$.

FRAŇKOVA, S. (Rsch. Ctr. of Metabolism \& Nutrition, Inst. of Clin. \& Exptl. Med., Prague, Czechoslovakia). Effect of early dietary and sensoric reduction on behaviour of adult rats. Activitas Nervosa Superior, 1972, 14, 1-7.

GREENOUGH, W. T. (Univ. of Illinois, Champaign, Ill. 61820), M A D D E N, T. C., \& FLEISCHMANN, T. B. Effects of isolation, daily handling, and enriched rearing on maze learning. Psychonomic Science, 1972, 27, 279-280.

GROTA, L. J. (Univ. of Rochester Sch. of Med. \& Dent., Rochester, N.Y. 14642), \& ADER, R. Effects of early experience with electric shock and dexamethasone on avoidance conditioning at adulthood. Psychonomic Science, 1972, 28, 10-12.

HENDERSON, N. D. (Oberlin Coll., Oberlin, Ohio 44074). Relative effects of early rearing environment and genotype on discrimination learning in house mice. Journal of Comparative \& Physiological Psychology, 1972, 79, 243-253.
HUNTLEY, M. J. (Univ. of Nebraska, Omaha, Nebr. 68132), \& NEWTON J. M. Effects of environmental complexity and locomotor activity on brain weight in the rat. Physiology \& Behavior, 1972, 8, 725-727.

JOFFE, J. M. (Univ. of Vermont, Burlington, Vt. 05401 ), MILKOVIĆ, K., \& LEVINE, S. Effects of changes in maternal pituitary-adrenal function on behavior of rat offspring. Physiology \& Behavior, 1972, 8, 425-430.

JOHNSON, R. N. (Ramapo Coll., Mahwah, N.J. 07430), DeSISTO, M. J., JR., \& KOENIG, A. B. Social and developmental experience and interspecific aggression in rats. Journal of Comparative \& Physiological Psychology, 1972, 79, 237-242.

KOMURA, S. (Dept. of Legal Med., Sch. of Med., Yamaguchi Univ., Ube, Japan), UEDA, M., \& KOBAYASHI, T. Effects of foster nursing on alcohol selection in inbred strains of mice. Quarterly Journal of Studies on Alcohol, 1972, 33, 494-503.

KURTZ, R. G., ROZIN, P., \& TEITELBAUM, P. (Univ. of Pennsylvania, Philadelphia, Pa. $\left.\begin{array}{lllll}1 & 9 & 1 & 0 & 4\end{array}\right)$. Ventromedial hypothalamic hyperphagia in the hypophysectomized weanling rat. Journal of Comparative \& Physiological Psychology, 1972, 80, 19-25.

MEYER, J. S. (Reg. Prim. Rsch. Ctr., Univ. of Wisconsin, Madison, Wis. 53706), \& BOWMAN, R. E. Rearing experience, stress and adrenocorticosteroids in the rhesus monkey. Physiology \& Behavior, 1972, 8, 339-343.

OSSENKOPP, K.-P. (Dept. of Ed., Univ. of Manitoba, Winnipeg 19, Man., Canada). Maturation and open-field behavior in rats exposed prenatally to an ELF low-intensity rotating magnetic field. Psychological Reports, 1972, 30, 371-374.

OUGH, B. R. (North Dakota State Univ., Fargo, N. Dak. 58102), BEATTY, W. W., \& KHALILI, J. Effects of isolated and enriched rearing on response inhibition. Psychonomic Science, 1972, 27, 293-294. 
PETERS, P. J. (Dept. of Zool., Univ. of Texas, Austin, Tex. 78712), BRONSON, F. H., \& WHITSETT, J. $M$. Neonatal castration and intermale aggression in mice. Physiology \& Behavior, 1972, 8, 265-268.

PORTER, R. H. (Univ. of Leicester, Leicester, England). Infantile handling differentially effects inter-strain dominance interactions in mice. Behavioral Biology, 1972, 7, 415-420.

SCHLOTTMANN, R. S. (Oklahoma State Univ., Stillwater, Okla. 74074), \& SEAY, B. Mother-infant separation in the java monkey (Macaca irus). Journal of Comparative \& Physiological Psychology, 1972, 79, 334-340.

SMITH, H. V. (Trinity Coll., Dublin 2, Ireland). Effects of environmental enrichment on open-field activity and Hebb-Williams problem solving in rats. Journal of Comparative \& Physiological Psychology, 1972, 80, $163-168$.

SUOMI, S. J. (Prim. Lab., Univ. of Wisconsin, Madison, Wis. 53706), \& HARLOW, H. F. Depressive behavior in young monkeys subjected to vertical chamber confinement. Journal of Comparative \& Physiological Psychology, 1972, 180, 11-18.

VOLKMAR, F. R. (Univ. of Illinois, Champaign, Ill. 61820), \& GREENOUGH, W. T. Rearing complexity affects branching of dendrites in the visual cortex of the rat. Science, 1972, 176, 1445-1447.

\section{Developmental Changes}

FEIGLEY, D. A., PARSONS, P. J., HAMILTON, L. W., \& SPEAR, N. E. (Rutgers-The State Univ., New Brunswick, N.J. 08903 ). Development of habituation to novel environments in the rat. Journal of Comparative \& Physiological Psychology, 1972, 79, 443-452.

RICCIO, D. C. (Kent State Univ., Kent, Ohio 44242), \& MARRAZO, M. J. Effects of punishing active avoidance in young and adult rats. Journal of Comparative \& Physiological Psychology, 1972, 79, 453-458.

WILLIAMS, J. T., JR. (Univ. of South Carolina, Columbia, S.C. 29208). Developmental age and the critical period for imprinting. Psychonomic Science, 1972, 27, 167-168.

\section{MOTIVATION \& EMOTION}

(Aggression, see Social Behavior; Frustration, see Reinforcement)

RICHMAN, C. L. (Wake Forest Univ., Winston-Salem, N.C. 27109), GULKIN, R., \& KNOBLOCK, K. Effects of bulbectomization, strain, and gentling on emotionality and exploratory behavior in rats. Physiology \& Behavior, 1972, 8, 447-452.

Activity \& Exploratory Behavior

FRANK, L. H. (Western Washington State Coll., Bellingham, Wash. 98225), \& MEYER, M. E. Activity as a function of salinity in two species of intertidal crab, Hemigrapsus oregonensis and Hemigrapsus nudus. Psychonomic Science, 1972, 27, 169-170.

HUTTON, R. S. (Univ. of Washington, Seattle, Wash. 98105), \& STEVENS, J. L. Scopolamine effects on forced exercise to exhaustion. Psychonomic Science, 1972, 27, 171-172.

KIR KBY, R. J., BELL, D. S. (Psychiat. Rsch. Unit, Callan Park Hosp., Rozelle, N.S.W., Australia, 2039), \& PRESTON, A. C. The effects of methylamphetamine on stereotyped behaviour, activity, startle, and orienting responses. Psychopharmacologia (Berlin), 1972, 25, 41-48.

PEELER, D. F., JR. (Dept. of Neurosurg., Univ. of Mississippi Med. Ctr., Jackson, Miss. 39216). Activity as a function of genetic variables and opportunity for exploration. Psychonomic Science, 1972, $27,176-178$.

SIECK, M. H. (Univ. of California, Riverside, Calif. 92502). The role of the olfactory system in avoidance learning and activity. Physiology \& Behavior, 1972, 8, 705-710.

THOMAS, J. B. (Oberlin Coll., Oberlin, Ohio 44074), \& VAN ATTA, L. Hyperirritability, lever-press avoidance, and septal lesions in the albino rat. Physiology \& Behavior, 1972, 8, 225-232.

\section{Locomotor Activity}

BEAUCHAMP, J. (State Univ. of New York, Binghamton, N.Y. 13901), DONOVICK, P. J., \& BURRIGHT, R. G. An automated system for long term and continuous computer compatible recording of feeding, drinking, and general activity behaviors of rodents. Physiology \& Behavior, 1972, 8, 765-768.

CARMAN, J. B. (Univ. of North Dakota, Grand Forks, N. Dak. 58201). Generalization of activity following discriminative punishment training. Psychonomic Science, 1972, 28, 19-21.

DAVIS, W. J. (Div. of Natural Sci.-I, Univ. of California, Santa Cruz, Calif. 95060), \& AYERS, J. L., JR. Locomotion: Control by positive-feedback optokinetic responses. Science, 1972, 177, 183-185.

GEYER, M. A. (Dept. of Psychiat.,
Sch. of Med., Univ. of California, San Diego, La Jolla, Calif. 92037), SEGAL, D. S., \& MANDELL, A. J. Effect of intraventricular infusion of dopamine and norepinephrine on motor activity. Physiology \& Behavior, 1972, 8, 653-658.

HINE, B. (Dept. of Pharmacol. \& Toxicol., Purdue Univ., Lafayette, Ind. 47907), \& PAOLINO, R. M. Increases in heart rate accompanying decreases in activity and defecation: Support for a dual-process theory of habituation? Behavioral Biology, 1972, 7, 427-433.

HUNTLEY, M. J. (Univ. of Nebraska, Omaha, Nebr. 68132), \& NEWTON, J. M. Effects of environmental complexity and locomotor activity on brain weight in the rat. Physiology \& Behavior, 1972, 8, 725-727.

LEATON, R. N. (Dartmouth Coll., Hanover, N.H. 03755), \& RECH, R. $H$. Locomotor activity increases produced by intrahippocampal and intraseptal atropine in rats. Physiology \& Behavior, 1972, 8, 539-541.

LYNCH, G. (Dept. of Psychobiol., Univ. of California, Irvine, Calif. 92650), \& CRAIN, B. Increased generalized activity following lesions of the caudal reticular formation. Physiology \& Behavior, $1972,8,747-750$.

OLIVERIO, A. (Laboratorio di Psicobiologia e Psicofarmacologia, C.N.R., R o m e, It a ly ), CASTELLANO, C., \& MESSERI, $P$. Genetic analysis of avoidance, maze, and wheel-running behaviors in the mouse. Journal of Comparative \& Physiological Psychology, 1972, 79, 459-473.

THIEL, V. (Depts. of Zool. \& Psychol., Univ. of Toronto, Toronto, Ont., Canada), BARNES, D. S., \& MROSOVSKY, N. A simple method for recording activity patterns of small animals. Physiology \& Behavior, 1972, 8, 549-551.

WILSON, D. M. (c/o Donald Kennedy, Dept. of Biol. Sci., Stanford Univ., Stanford, Calif. 94305). Genetic and sensory mechanisms for locomotion and orientation in animals. American Scientist, 1972, $60,358-365$.

\section{Exploratory Behavior}

GAMMON, W, D. (Florida Atlantic Univ., Boca Raton, Fla. 33432), SINGER, J. J., \& MICHELS, K. M. Visual exploratory behavior in the squirrel monkey (Saimiri sciureus). Perceptual \& Motor Skills, 1972, 34, 715-718.

HUGHES, R. N. (Univ. of Canterbury, Canterbury, New Zealand). 
Chlordiazepoxide modified exploration in rats. Psychopharmacologia (Berlin), $1972,24,462-469$.

MIKULKA, P. (Old Dominion Univ., Norfolk, Va. 23508), KENDALL, P., CONSTANTINE, J., \& PORTERFIELD, L. The effect of Pavlovian CS+ and CS- on exploratory behavior. Psychonomic Science, 1972, 27, 308-310.

VAN ABEELEN, J. (Genetics Lab., Univ. of Nijmegen, Nijmegen, The Netherlands), GILISSEN, L., HANSSEN, T., \& LENDERS, A. Effects of intrahippocampal injections with methylscopolamine and neostigmine upon exploratory behaviour in two inbred mouse strains. Psychopharmacologia (Berlin), 1972, 24, 470-475.

\section{Hunger \& Thirst}

BEAUCHAMP, J. (State Univ. of New York, Binghamton, N.Y. 13901), DONOVICK, P. J., \& BURRIGHT, R. G. An automated system for long term and continuous computer compatible recording of feeding, drinking, and general activity behaviors of rodents. Physiology \& Behavior, 1972, 8, 765-768.

LOCKARD, J. S. (Dept. of Neurol. Surg., Univ. of Washington, Seattle, Wash. 98195), EHLE, A. L., \& FOLTZ, E. L. Diurnal variation of ileum motility in monkey during different feeding and avoidance-conditioning schedules. Physiology \& Behavior, 1972, 8, $195 \cdot 200$.

MENDELSON, J. (Univ. of Kansas, Lawrence, Kans. 66044), \& ZEC, R. Effects of lingual denervation and desalivation on airlicking in the rat. Physiology \& Behavior, 1972, 8, 711-714.

RUSSEK, M. (Escuela Nacional de Ciencias Biológicas, Instituto Ploitécnico Nacional, México, 17 D.F., México), \& STEVENSON, J. A. F. Correlation between the effects of several substances on food intake and on the hepatic concentration of reducing sugars. Physiology \& Behavior, 1972, 8, 245-249.

SLANGEN, J. L. (Rudolf Magnus Inst. for Pharmacol., Med. Faculty, Univ. of Utrecht, Vondellaan 6, Utrecht, The Netherlands), \& WEIJNEN, J. A. W. M. The reinforcing effect of electrical stimulation of the tongue in thirsty rats. Physiology \& Behavior, 1972, 8, 565-568.

STRONGMAN, K. T. (Exeter Univ., Exeter, Devon, England), WOOKEY, J. A., \& WOOKEY, P. E. Handling and food intake in hooded rats. Psychological Reports, 1972, 30,678 .
Deprivation

COHEN, P. S. (Florida State Univ., Tallahassee, Fla. 32306), \& TOKIEDA, F. K. Sucrose-water preference reversal in the water-deprived rat. Journal of Comparative \& Physiological Psychology, 1972, 79, 254-258.

FECHTER, L. D. (Labs. of Exptl. \& Physiol. Psychol., Univ. of Rochester Med. Ctr., Rochester, N.Y. 14620), \& ISON, J. R. The inhibition of the acoustic startle reaction in rats by food and water deprivation. Learning \& Motivation, 1972, 3, 109-124.

MARSDEN, H. M. (Natl. Inst. of Neurol. Diseases \& Stroke, Section on Behav. Systems, Lab. of Brain Evol. \& Behav. (NIMH), Bldg. 112, NIHAC, 9000 Rockville Pike, Bethesda, Md. 20014). The effect of food deprivation on intergroup relations in rhesus monkeys. Behavioral Biology, 1972, 7, 369-374.

MAYER, A. J. (Univ. of Texas, Arlington, Tex. 76010), \& COX, V. C. Serum osmolality and meal initiation in food and water-deprived rats. Behavioral Biology, 1972, 7, 435-439.

SACHS, B. D. (Univ. of Connecticut, Storrs, Conn. 06268), \& MARSAN, E. Male rats prefer sex to food after 6 days of food deprivation. Psychonomic Science, 1972, 28, 47-49.

SPENCER, J. (Dept. of Psychiat. \& Behav. Sci., Univ. of Oklahoma Health Sci. Ctr., 800 N.E. 13, P.O. Box 26901, Oklahoma City, Okla. 73190), \& HOLLOWAY, F. A. Differentiation between carbachol a $n$ d s e r i n e d u ri ng deprivation-induced drinking in the rat. Psychonomic Science, 1972, 28, 16-18.

\section{Physiological Factors}

MENDELSON, J. (Univ. of Kansas, Lawrence, Kans. 66044 ), ZEC, R., \& CHILLAG, D. Effects of desalivation on drinking and air licking induced by water deprivation and hypertonic saline injections. Journal of Comparative \& Physiological Psychology, 1972, 80, 30-42.

MIKHAIL, A. (Univ. of Manitoba, Winnipeg, Man., Canada) \& HIRSCHBERG, J. Ulceration in the rat's forestomach: Its reduction by non-nutritive bulky substances. Physiology \& Behavior, 1972, 8, 769-770.

ROLLS, B. J. (Dept. of Exptl. Psychol., Univ. of Oxford, Oxford, OXI 3PS, England), \& JONES, B. P. Cessation of drinking following intracranial injections of angiotensin in the rat. Journal of Comparative \&
Physiological Psychology, 1972, 80, 26-29.

STEPHAN, F. K. (Univ. of California, Berkeley; Calif. 94720), \& ZUCKER, I. Rat drinking rhythms: Central visual pathways and endocrine factors mediating responsiveness to environmental illumination. Physiology \& Behavior, 1972, 8, 315-326.

THORNTON, L. W. (Univ. of Wyoming, Laramie, Wyo. 82070), \& WETTER, B. D. Blood osmolality changes in sheep at satiety. Psychonomic Science, 1972, 27, 155-156.

WADE, G. N. (Inst. of Animal Behav., Rutgers Univ., Newark, N.J. 07102). Gonadal hormones and behavioral regulation of body weight. Physiology \& Behavior, 1972, 8, 523-534.

WORK, M. S. (Sacramento State Coll., Sacramento, Calif. 95819), \& ROGERS, H. Effect of estrogen level on food-seeking dominance among male rats. Journal of Comparative \& Physiological Psychology, 1972, 79, 414-418.

\section{Brain Function}

BOLLINGER, S. F. (Univ. of Alabama, Birmingham, Ala. 35233), FAIRCLOTH, K. P., \& DOERING, R. M. The instrumental response and hypothalamic stimulus-bound drinking. Physiology \& Behavior, 1972, 8, 377-381.

CAMPos, G. B. (Neurol. Dept., Federal Univ. of Minas Gerais, Belo Horizonte, MG, Brazil), JOHNSON, J. I., JR., \& BOMBARDIERI, R. A., JR. Organization of tactile thalamus and related behavior in the agouti, Dasyprocta aguti. Physiology \& Behavior, 1972, 8, 553-556.

CAUL, W. F. (Vanderbilt Univ., Nashville, Tenn. 37203), \& BARRETT, R. J. Electroconvulsive shock effects on conditioned heart rate and suppression of drinking. Physiology \& Behavior, 1972, 8, 287-290.

GOLD, R. M. (State Univ. of New York, Cortland, N.Y. 13045), \& PROULX, D. M. Bait-shyness acquisition is impaired by $\mathrm{VMH}$ lesions that produce obesity. Journal of Comparative \& Physiological Psychology, 1972, 79, 201-209.

GOLD, R. M. (State Univ. of New York, Cortland, N.Y. 13045), QUACKENBUSH, P. M., \& KAPATOS, G. Obesity following combination of rostrolateral to VMH cut and contralateral mammillary area lesion. Journal of Comparative \& Physiological Psychology, 1972, 79, 210-218.

KURTZ, R. G., ROZIN, P., \& TEITELBAUM, P. (Úniv. of 
Pennsylvania, Philadelphia, $\mathrm{Pa}$. $\left.\begin{array}{llllll}1 & 9 & 1 & 0 & 4\end{array}\right)$. Ventrom ed i a l hypothalamic hyperphagia in the hypophysectomized weanling rat. Journal of Comparative \& Physiological Psychology, 1972, 80, 19-25.

PAXINOS, G. (McGill Univ., Montreal, P.Q., Canada), \& BINDRA, D. Hypothalamic knife cuts: Effects on eating, drinking, irritability, aggression, and copulation in the male rat. Journal of Comparative \& Physiological Psychology, 1972, 79, $219 \cdot 229$

WILCOVE, W. G. (Indiana Univ. Bloomington, Ind. 47401), \& VANCE, $W$. B. The effects of olfactory and frontal pole lesions on the drinking response to hypertonic loading in rats. Psychonomic Science, 1972, 27, 295-298.

YAKSH, T. L. (Lab. of Neuropsychol., Purdue Univ., Lafayette, Ind. 47907), \& MYERS, R. D. Hypothalamic "coding" in the unanesthetized monkey of noradrenergic sites mediating feeding and thermoregulation. Physiology \& Behavior, 1972, 8, 251-257.

\section{Polydipsia}

FREED, E. X. (Alcohol Rsch. Lab. VA Hosp., Lyons, N.J. 07939). Alcohol polydipsia in the rat as a function of caloric need. Quarterly Journal of Studies on Alcohol, 1972, 33, 504-507

MEISCH, R. A. (Depts. of Pharmacol. \& Psychiat., Univ. of Minnesota, Minneapolis, Minn. 55455), \& THOMPSON, T. Ethanol intake during schedule-induced polydipsia. Physiology \& Behavior, 1972, 8, 471-475.

MINEKA, S. (Univ. of Pennsylvania, Philadelphia, Pa. 19104), SELIGMAN, M. E. P., HETRICK, M., \& ZUELZER, K. Poisoning and conditioned drinking. Journal of Comparative \& Physiological Psychology, 1972, 79, 377-384.

PONICKI, E. (Psychiat. Rsch. Unit Univ. of Minnesota, Minneapolis, Minn. 55455), \& THOMPSON, T The effects of extinction of food-reinfored responding on schedule-induced polydipsia. Psychonomic Science, 1972, 28, 5-6.

\section{Preferences}

CAREY, R. J. (State Univ. of New York, Upstate Med. Ctr., Syracuse, N.Y. 13210). A decrease in ethanol preference in rats resulting from forced ethanol drinking under fluid deprivation. Physiology \& Behavior, $1972,8,373-375$.

COHEN, P. S. (Florida State Univ., Tallahassee, Fla. 32306), \&
TOKIEDA, F. K. Sucrose-water preference reversal in the water-deprived rat. Journal of Comparative \& Physiological Psychology, 1972, 79, 254-258.

KRECEK, J. (Inst. of Physiol. of the Czechoslovak Acad. of Sci., Prague, Czechoslovakia), NOVÁKOVÁ, V., \& STIBRAL, K. Sex differences in the taste preference for a salt solution in the rat. Physiology \& Behavior, 1972, 8, 183-188.

MARKS, H. E. (Univ. of Georgia, Athens, Ga. 30601), \& MILLER, C. $R$. Development of hypothalamic obesity in the male golden hamster (Mesocricetus auratus) as a function of food preference. Psychonomic Science, 1972, 27, 263-265.

MYERS, R. D. (Lab. of Neuropsychol., Purdue Univ., Lafayette, Ind. 47907), VEALE, W. L. \& YAKSH, T. L. Preference for ethanol in the rhesus monkey following chronic infusion of ethanol into the cerebral ventricles. Physiology \& Behavior, 1972, 8, 431-435.

WAYNER, M. J. (Brain Rsch. Lab., Syracuse Univ., 601 University Ave., Syracuse, N.Y. 13210), GREENBERG, I., TARTAGLIONE, R., NOLLEY, D., FRALEY, S., \& COTT, A. A new factor affecting the consumption of ethyl alcohol and other sapid fluids. Physiology \& Behavior, 1972, 8, 345-362.

ZAHORIK, D. M. (Univ. of Illinois, $\mathrm{Champaign,} \mathrm{Ill.61820).}$ Conditioned physiological changes associated with learned aversions to tastes paired with thiamine deficiency in the rat. Journal of Comparative \& Physiological Psychology, 1972, 79, 189-200.

\section{Appetite \& Self-Selection}

BRILL, W. A. (Monell Chem. Senses Ctr., Univ. of Pennsylvania, Philadelphia, Pa. 19104), \& MALLER, O. Selection and intake of sugars by desalivated rats. Behavioral Biology, 1972, 7, 445-452.

KAKOLEWSKI, J. W. (Univ. of South Dakota, Sch. of Med., Vermillion, S. Dak. 57069), \& DEAUX, E. Aphagia in the presence of drinking an isosmotic $\mathrm{NaCl}$ solution. Physiology \& Behavior, 1972, 8, $623-630$

KEEHN, J. D. (Alcoholism \& Drug Addiction Rsch. Fdtn. \& York Univ., Toronto, Ont., Canada), \& COULSON, G. E. Schedule control of alcohol versus water selection by rats. Quarterly Journal of Studies on Alcohol, 1972, 33, 395-399.

KOMURA, S. (Dept. of Legal Med., Sch. of Med., Yamaguchi Univ., Ube, Japan), UEDA, M., \& KOBAYASHI, T. Effects of foster nursing on alcohol selection in inbred strains of mice. Quarterly Journal of Studies on Alcohol, 1972, 33, 494-503.

LESHNER, A. I. (Bucknell Univ., Lewisburg, $\mathrm{Pa}$. 17837). The effects of a dren alectomy on protein-carbohydrate choice. Psychonomic Science, 1972, 27, 289-290.

M Y ER S, R. D. (Lab. of Neuropsychol., Purdue Univ., Lafayette, Ind. 47907.), \& TYTELL, M. Volitional consumption of flavored ethanol solution by rats: The effects of pCPA, and the absence of tolerance. Physiology \& Behavior, 1972, 8, 403-408.

NANCE, D. M. (Worcester Fdtn. for Exptl. Biol., 222 Maple Ave., Shrewsbury, Mass. 01545), \& KILBEY, M. M. Self-selection of 5 - hydroxytryptophan in Dl-para-chlorophenylalanine treated rats. Physiology \& Behavior, 1972 , $8,545-547$

\section{Drug Effects}

BLACKBURN, J. G. (Med. Univ, of South Carolina, Charleston, S.C. 29401). Chloralose and food intake in rats. Physiology \& Behavior, 1972, 8, 791-792.

KOOPMANS, H. S. (Univ. of California, San Diego, La Jolla, Calif. 92037), DEUTSCH, J. A., \& BRANSON, P. J. The effect of cholecystokinin-pancreozymin on hunger and thirst in mice. Behavioral Biology, 1972, 7 , 441-444.

LEVITT, R. A. (Southern Illinois Univ., Carbondale, Ill. 62901), \& O'HEARN, J. Y. Drinking elicited by cholinergic stimulation of CNS fibers. Physiology \& Behavior, 1972, 8, 641-644.

OVERSTREET, D. H. (Dept. of Psychobiol., Univ. of California, Irvine, Calif. 92664), HADICK, D. G., \& RUSSELL, R. W. Effects of amphetamine and pilocarpine on eating behavior in rats with chronically low acetylcholinesterase levels. Behavioral Biology, 1972, 7, 217-226.

TERPSTRA, G. K. (Rudolf Magnus Inst. for Pharmacol., Med. Faculty, Univ. of Utrecht, Vondellaan 6, Utrecht, The Netherlands) \& SLANGEN, J. L. Central blockade of (methyl-)atropine on carbachol drinking: A dose-response study. Physiology \& Behavior, 1972, 8, 715-719.

Sexual \& Maternal Behavior BARFIELD, R. J. N.J. 08903), \& GEYER, L. A. Sexual behavior: Ultrasonic postejaculatory song of the male rat. Science, 1972,176 , 1349-1350. 
EDMONDS, S. (Univ. of Pennsylvania, Philadelphia, Pa. 19104), ZOLOTH, S. R., \& ADLER, N. T. Storage of copulatory stimulation in the female rat. Physiology \& Behavior, 1972, 8, 161-164.

EVERITT, B. J. (Dept. of Anat., Univ. of Birmingham, Birmingham B15 2T\}, England), HERBERT, J., \& HAMER, J. D. Sexual receptivity of bilaterally adrenalectomised female rhesus monkeys. Physiology \& Behavior, 1972, 8, 409-415.

HERRENKOHL, L. R. (Temple Univ., Philadelphia, Pa. 19122), \& ROSENBERG, P. A. Exteroceptive stimulation of maternal behavior in the naive rat. Physiology \& Behavior, 1972, 8, 595-598.

LEON, M. (Univ. of Chicago, Chicago, III. 60637), \& MOLTZ, $H$. The development of the pheromonal bond in the albino rat. Physiology \& Behavior, 1972, 8, 683-686.

PARROTT, R. F. (Dept. of Physiol., Royal Veterinary Coll., Royal College St., London, England), \& SMITH, K. S. A punched tape apparatus for computer analysis of male rat sexual behaviour. Physiology \& Behavior, 1972, 8, 787-789.

PAXINOS, G. (McGill Univ., Montreal, P.Q., Canada), \& BINDRA, D. Hypothalamic knife cuts: Effects on eating, drinking, irritability, aggression, and copulation in the male rat. Journal of Comparative \& Physiological Psychology, 1972, 79, 219-229.

PETERS, P. J. (Dept. of Zool., Univ. of Texas, Austin, Tex. 78712), BRONSON, F. H., \& WHITSETT, J. $M$. Neonatal castration and intermale aggression in mice. Physiology \& Behavior, 1972, 8, 265-268.

POWERS, J. B. (Neurosci. Lab., Univ. of Michigan, Ann Arbor, Mich. 48104), \& VALENSTEIN, E. S. Individual differences in sexual responsiveness to estrogen and progesterone in ovariectomized rats. Physiology \& Behavior, 1972, 8, $673-676$.

SACHS, B. D. (Univ. of Connecticut, Storrs, Conn. 06268), \& MARSAN, E. Male rats prefer sex to food after 6 days of food deprivation. Psychonomic Science, 1972, 28, 47-49.

WALLEN, $\mathrm{K}$. (Univ. of California, Berkeley, Calif. 94720 ), GOLDFOOT, D. A., JOSLYN, W. D. \& PARIS, C. A. Modification of behavioral estrus in the guinea pig following intracranial cycloheximide. Physiology \& Behavior, 1972, 8, 221-223.

WHALEN, R. E. (Dept. of Psychobiol., Univ. of California, Irvine, Calif. 92664 ), BATTIE, C.,
\& LUTTGE, W. G. Anti-estrogen inhibition of androgen induced sexual receptivity in rats. Behavioral Biology, 1972, 7, 311-320.

\section{Fear \& Immobility}

CAUL, W. F. (Vanderbilt Univ., Nashville, Tenn. 37203 ), BUCHANAN, D. C., \& HAYS, R. C. Effects of unpredictability of shock on incidence of gastric lesions and heart rate in immobilized rats. Physiology \& Behavior, 1972, 8, 669-672.

DMITRUK, V. M. (Grand Valley State Coll., Allendale, Mich. 49401), \& ROOSSIEN, J. R. Emotionality of rats stimulated in infancy: Effects of intensity and predictability of shock. Psychological Reports, 1972, 30, 555-559.

IMADA, H. (Kwansei Gakuin Univ., Nishinomiya, Hyogo, Japan). Emotional reactivity and conditionability in four strains of rats. Journal of Comparative \& Physiological Psychology, 1972, 79, 474-480

OSSENKOPP, K.P. (Dept. of Ed., Univ. of Manitoba, Winnipeg 19, Man., Canada). Maturation and open-field behavior in rats exposed prenatally to an ELF low-intensity rotating magnetic field. Psychological Reports, 1972, 30, 371-374.

SMITH, H. V. (Trinity Coll., Dublin 2, Ireland). Effects of environmental enrichment on open-field activity and Hebb-Williams problem solving in rats. Journal of Comparative \& Physiological Psychology, 1972, 80, 163-168.

THORNE, B. M. (Louisiana State Univ., Baton Rouge, La. 70803). Brain lesions and affective behavior in primates: A selected review. Journal of General Psychology, 1972, 86, 153-162.

TORTORA, D. F. (Michigan State Univ., East Lansing, Mich. 48823), \& BORCHELT, P. L. The effect of escape responses on immobility in bobwhite quail (Colinus virginianus). Psychonomic Science, 1972, 27, 129-130.

\section{Sleep}

BERGER, R. J. (Div. of Natural Sci. I, Univ. of California, Santa Cruz, Calif. 95060), \& WALKER, J. M. Sleep in the burrowing owl (Speotyto cunicularia hypugaea). Behavioral Biology, 1972, 7, 183-194.

HARTMANN, E. (Sleep \& Dream Lab., 591 Morton St., Boston, Mass. 01545 ), \& STERN, W. C. Desynchronized sleep deprivation: Learning deficit and its reversal by increased catecholamines.
Physiology \& Behavior, 1972, 8, 585-587.

SCHMIDEK, W. R. (Depto. Fisiologia, Fac. Medicina USP, Cx. Postal 2921, São Paulo, SP, Brazil), HOSHINO, K., SCHMIDEK, M., \& TIMO-IARIA, C. Influence of environmental temperature on the sleep-wakefulness cycle in the rat. Physiology \& Behavior, 1972, 8, 363-371.

VAN TWYVER, H. (Florida Tech. Univ., Orlando, Fla. 32816), \& GARRETT, W. Arousal threshold in the rat determined by "meaningful" stimuli. Behavioral Biology, 1972, 7, 205-215.

WALKER, J. M. (Div. of Natural Sci., Univ. of California, Santa Cruz, Calif. 95060), \& BERGER, R. J. Sleep in the domestic pigeon (Columba livia). Behavioral Biology, 1972, 7, 195-203.

\section{SOCIAL \& ABNORMAL BEHAVIOR}

GREGOR, G. L. (Univ. of Utah, Salt Lake City, Utah 84112), SMITH, R. F., SIMONS, L. S., \& PARKER, H. B. Behavioral consequences of crowding in the deermouse (Peromyscus maniculatus). Journal of Comparative \& Physiological Psychology, 1970, 79, 488-493.

HARLESS, M. D. (Midwestern Univ., Wichita Falls, Tex. 76038). Group operant behavior in free-feeding squirrel monkeys. Psychological Reports, $1972,30,572-574$.

LESHNER, A. I. (Bucknell Univ., Lew isburg, Pa. 17837$), \quad$ \& CANDLAND, D. K. Endocrine effects of grouping and dominance rank in squirrel monkeys. Physiology \& Behavior, 1972, 8, 441-445.

SUOMI, S. J. (Prim. Lab., Univ. of Wisconsin, Madison, Wis. 53706), \& HARLOW, H. F. Depressive behavior in young monkeys subjected to vertical chamber confinement. Journal of Comparative \& Physiological Psychology, 1972, 180, 11-18.

BANDLER, R. J., JR. (Dept. of Psychiat., Yale Univ. Sch. of Med. \& Rsch. Facilities, Connecticut Mental Health Ctr., New Haven, Conn. 06519), \& CHI, C. C. Effects of olfactory bulb removal on aggression: A reevaluation. Physiology \& Behavior, 1972, 8, 207-211.

BRACCO, H. F. (Waverly Mental Health Ctr., 8101 Dixie Hwy., Louisville, Ky. 40258), \& MILLER, L. L. Effects of varying shock intensities on pain-elicited aggression in the domestic fowl. 
Perceptual \& Motor Skills, 1972, 34, 719-723.

BRAIN, P. F. (Dept. of Zool., Univ. Coll. of Swansea, Swansea, Glamorganshire, Wales). Effects of is olation/grouping on endocrine function and fighting behavior in male and female golden hamsters (Mesocricetus auratus Waterhouse). Behavioral Biology, 1972, 7, 349-357.

CARDER, B. (Univ, of California, Los Angeles, Calif. 90024), \& OLSON, J. Marihuana and shock induced aggression in rats. Physiology \& Behavior, 1972, 8, 599-602.

CLARK, L. D. (Dept. of Psychiat., Univ. of Utah Coll. of Med., Salt Lake City, Utah 84112), \& NAKASHIMA, E. N. Measurement of social dominance in squirrel monkeys. Behavior Research Methods \& Instrumentation, 1972, 4, 143-144.

GALLAGHER, J. E. (Univ. of California, San Francisco, Calif. 94102), HERZ, M. J., \& PEEKE, H. V.S. Habituation of aggression: The effects of visual social stimuli on behavior between adjacently territorial convict cichlids (Cichlasoma nigrofasiatum). Behavioral Biology, 1972, 7 , 359-368.

HARDING, C. F. (Bucknell Univ., Lew isburg, Pa. 17837), \& LESHNER, A. I. The effects of adrenalectomy on the aggressiveness of differently housed mice. Physiology \& Behavior, 1972, 8, 437-440.

HASSELAGER, E. (Sct. Hans Hosp., Dept. E, 4000 Roskilde, Denmark), ROLINSKI, Z., \& RANDRUP, A. Specific antagonism by dopamine inhibitors of items of amphetamine induced aggressive behaviour. Psychopharmacologia (Berlin), $1972,24,485-495$

HUTZELL, R. R., \& KNUTSON, J. F (Univ. of Iowa, Iowa City, Iowa 52240 ). A comparison of shock-elicited fighting and shock-elicited biting in rats. Physiology \& Behavior, 1972, 8, 477-480.

JOHNSON, H. G. (Univ. of California \& Langley Porter Neuropsychiat. Inst., San Francisco, Calif. 94122), \& PEEKE, H. V. S. Patterns of intra- and interspecific aggression in labyrinth fish (Belontiidae). Behavioral Biology, 1972, 7 , 335-347.

JOHNSON, R. N. (Ramapo Coll., Mahwah, N.J. 07430), DeSISTO, M. J., JR., \& KOENIG, A. B. Social and developmental experience and interspecific aggression in rats. Journal of Comparative \& Physiological Psychology, 1972, 79, 237-242.
LEE, C. T. (Brooklyn Coll., CUNY, Brooklyn, N.Y. 11210), \& BRAKE, S. C. Reaction of male mouse fighters to male castrates treated with testosterone propionate or oil. Psychonomic Science, 1972, 27, 287-288.

MacDONNELL, M. F. (Ctr. of Alcohol Studies, Rutgers Univ., New Brunswick, N.J. 08903), \& FESSOCK, L. Some effects of ethanol, amphetamine, disulfiram and $p$-CPA on seizing of prey in feline predatory attack and on associated motor pathways. Quarterly Journal of Studies on Alcohol, 1972, 33, 437-450.

MARSDEN, $H$. M. (Natl. Inst. of Neurol. Diseases \& Stroke, Sec. on Behav. Systems, Lab. of Brain Evol. \& Behav. (NIMH), Bldg. 112, NIHAC, 9000 Rockville Pike, Bethesda, Md. 20014). The effect of food deprivation on intergroup relations in rhesus monkeys. Behavioral Biology, 1972, 7, 369-374.

MORGRET, M. K. (Washington State Univ., Pullman, Wash. 99163), \& DENGERINK, H. A. The squeal as an indicator of aggression in mice. Behavior Research Methods \& Instrumentation, 1972, 4, 138-140.

PAXINOS, G. (McGill Univ., Montreal, P.Q., Canada), \& BINDRA, D. Hypothalamic knife cuts: Effects on eating, drinking, irritability, aggression, and copulation in the male rat. Journal of Comparative \& Physiological Psychology, 1972, 79, 219-229.

PAYNE, A. P. (Dept. of Anat., Med. Sch., Univ. of Birmingham, Birmingham B15 2TJ, England), \& SWANSON, H. H. The effect of sex hormones on the agonistic behavior of the male golden hamster (Mesocricetus auratus Waterhouse). Physiology \& Behavior, 1972, 8, 687-691.

PETERS, P. J. (Dept. of Zool., Univ. of Texas, Austin, Tex. 78712), BRONSON, F. H., \& WHITSETT, J. $M$. Neonatal castration and intermale aggression in mice. Physiology \& Behavior, 1972, 8, 265-268.

PORTER, R. H. (Univ. of Leicester, Leicester, England). Infantile handling differentially effects inter-strain dominance interactions in mice. Behavioral Biology, 1972, 7, 415-420.

SCHREIBER， R. A. (Dept. of Biochem., Med. Univ. of South Carolina, Charleston, S.C. 29401), $\&$ SCHLESINGER, K. Circadian rhythms and seizure susceptibility: Effects of manipulations of light cycles on susceptibility to audiogenic seizures and on levels of 5-hydroxytryptamine and norepinephrine in brain. Physiology \& Behavior, 1972, 8, 699-703.

SLOTNICK, B. M. (Lab. of Brain Evol. \& Behav., NIMH, Bethesda, Md. 20017), \& McMULLEN, M. F. Intraspecific fighting in albino mice with septal forebrain lesions. Physiology \& Behavior, 1972, 8, 333-337.

STARK, B. (Dept. of Biol., Yale Univ., New Haven, Conn. 06520), \& HAZLETT, B. A. Effects of olfactory experience on aggression in Mus musculus and Peromyscus maniculatus. Behavioral Biology, 1972, 7, 265-269.

TONDAT, L. M., \& DALY, H. B. (State Univ. of New York, Oswego, N.Y. 13126). The combined effects of frustrative nonreward and shock on aggression between rats. Psychonomic Science, 1972, 28, 25-28.

VALE, J. R. (Univ. of California, Berkeley, Calif. 94720), RAY, D., \& VALE, C. A. The interaction of genotype and exogenous neonatal androgen: Agonistic behavior in female mice. Behavioral Biology, $1972,7,321-334$.

VOGEL, J. R. (Squibb Inst. for Med. Rsch., New Brunswick, N.J. 08903), \& LEAF, R. C. Initiation of mouse killing in non-killer rats by repeated pilocarpine treatment. Physiology \& Behavior, 1972, 8, 421-424.

\section{Territoriality}

EGAN, O. (Univ. of Alberta, Edmonton, Alta., Canada), ROYCE, J. R., \& POLEY, W. Evidence for a territorial marking factor of mouse emotionality. Psychonomic Science, 1972, 27, 272-274.

\section{SENSORY FUNCTIONS Vision}

MASSOF, R. W. (Indiana Univ., Div. of Optom., 800 E. Atwater, Bloomington, Ind. 47401), \& CHANG, F. W. A revision of the rat schematic eye. Vision Research, $1972,12,793-796$.

SANDERSON, K. J. (Dept. of Physiol., John Curtin Sch. of Med. Rsch., Australian National Univ., Canberra, A.C.T., Australia). Does rolling of the eye occur in the anaesthetized paralysed cat? Vision Research, 1972, 12, 1045-1050.

WILSON, D. M. (c/o Donald Kennedy, Dept. of Biol. Sci., Stanford Univ., Stanford, Calif. 94305). Genetic and senspry mechanisms for locomotion and orientation in animals. American Scientist, 1972, $60,358-365$.

\section{Visual Pathways}

HAMASAKI, D. I. (Bascom Palmer Eye Inst., Dept. of Ophthalmol., Univ. of Miami Sch. of Med., Miami, 
Fla. 33136), \& POLLACK, J. G. Depression of the late receptor potential and the ERG by light deprivation in cats. Vision Research, $1972,12,835-842$.

HAMASAKI, D. I. (Bascom Palmer Eye Inst., Dept. of Ophthalmol., Univ. of Miami Sch. of Med., Miami, Fla. 33136), RACKENSPERGER, W., \& VESPER, J. Spatial organization of normal and visually deprived units in the lateral geniculate nucleus of the cat. Vision Research, 1972, 12, 843-854.

HANITZSCH, R. (Carl-LudwigInstitut für Physiologie, Leipzig, DDR, Germany). Fast intraretinal potentials of the isolated mammalian retina. Vision Research, 1972, 12, 781-791.

HOOD, D. C. (Columbia Univ., New York, N.Y. 10027). Adaptational changes in the cone system of the isolated frog retina. Vision Research, 1972, 12, 875-888.

MAINSTER, M. A. (Life Sci. Div., Technology Inc., $8531 \quad N$. New Braunfels Ave., San Antonio, Tex. 78217 ), \& WHITE, T. J. Photoproducts of retinal photopigments and visual adaptation. Vision Research, 1972, $12,805-823$.

RIGGS, L. A. (Brown Univ., Providence, R.I. 02912), BLOUGH, P. M., \& SCHAFER, K. L. Electrical responses of the pigeon eye to changes in wavelength of the stimulating light. Vision Research, 1972, 12, 981-991.

RODIECK, R. W. (Dept. of Physiol., Univ. of Sydney, Sydney, A ustralia). Components of the electroretinogram-A reappraisal. Vision Research, 1972, 12 , 773-780.

STEPHAN, F. K. (Univ. of California, Berkeley, Calif. 94720), \& ZUCKER, I. Rat drinking rhythms: Central visual pathways and endocrine factors mediating responsiveness to environmental illumination. Physiology \& Behavior, 1972, 8, 315-326.

TEYLER, T. J. (Dept. of Psychobiol., Univ. of California, Irvine, Calif. 92664), SHAW, C., \& THOMPSON, R. F. Unit responses to moving visual stimuli in the motor cortex of the cat. Science, 1972, 176, 811-813.

VOLKMAR, F. R. (Univ. of Illinois, Champaign, Ill. 61820), \& GREENOUGH, W. T. Rearing complexity affects branching of dendrites in the visual cortex of the rat. Science, 1972, 176, 1445-1447.

Visual Sensitivity

BOYNTON, R. M. (Ctr. for Vis. Sci., Univ. of Rochester, Rochester, N.Y. 14627), \& WHITTEN, D. N.
Selective chromatic adaptation in primate photoreceptors. Vision Research, 1972, 12, 855-874.

HOOD, D. C. (Columbia Univ., New York, N.Y. 10027). Suppression of the frog's cone system in the dark. Vision Research, 1972, 12, 889-907.

JACOBS, G. H. (Univ. of California, Santa Barbara, Calif. 93106). Increment-threshold spectral sensitivity in the squirrel monkey. Journal of Comparative \& Physiological Psychology, 1972, 79, 425-431.

MESSING, R. B. (Rutgers Univ., Camden, N.J. 08102). The sensitivity of albino rats to lights of different wavelength: A behavioral assessment. Vision Research, 1972, $12,753-761$.

WRIGHT, A. A. (Univ. of Texas Grad. Sch. of Biomed. Sci., 6420 Lamar Fleming Blvd., Texas Med. Ctr., Houston, Tex. 77025). The influence of ultraviolet radiation on the pigeon's color discrimination. Journal of the Experimental Analysis of Behavior, 1972, 17, 325-337.

\section{Perception}

ASHIDA, S. (State Univ. of New York, Brockport, N.Y, 14420). Monocular depth perception in rats. Psychological Reports, 1972, 30, 427-433.

MALDONADO, H. (Centro de Biofísica $y$ Bioquímica, Instituto Venezolano de Investigaciones Científicas (IVIC), Apartado 1827, Caracas, Venezuela), \& RODRIGUEZ, E. Depth perception in the praying mantis. Physiology \& Behavior, 1972, 8, 751.759.

MASTERS, H. G. (Juniata Coll., Huntingdon, $\mathrm{Pa}$. 16652), \& PODGORSKI, C. Perception by cebus monkeys: I. Psychophysical judgments of minimal cylindrical volume differences by nonhuman and human subjects. Psychonomic Science, 1972, 28, 1-4.

SCHWARTZ, A. S. (Div. of Neurobiol., Barrow Neurol. Inst. of St. Joseph's Hosp. \& Med. Ctr., Phoenix, Ariz. 85013 ). Electrophysiological correlates of flicker perception in the cat. Physiology \& Behavior, 1972, 8, $603-609$.

\section{Audition}

CLOPTON, B. M. (Univ, of California, Santa Barbara, Calif. 93106). Detection of increments in noise intensity by monkeys. Journal of the Experimental Analysis of Behavior, 1972, 17, 473-481.

GAUTIER, H. (Laboratoire de Physiologie, Faculté de Medécine Saint-Antoine, 27 rue Chaligny,
Paris 12, France). Respiratory and heart rate responses to auditory stimulations. Physiology \& Behavior, 1972, 8, 327-332.

HAMMOND, G. R. (Univ. of Rochester, Rochester, N.Y. 14627), McADAM, D. W., \& ISON, J. R. Effects of prestimulation on the electromyographic response associated with the acoustic startle reaction in rats. Physiology \& Behavior, 1972, 8, 535-537.

HENRY, K. R. (Univ. of California, Davis, Calif. 95616). Unilateral increase of auditory sensitivity following early auditory exposure. Science, 1972, 176, 689-690.

KHANNA, S. M. (Fowler Mem. Lab., Dept. of Otolaryngol., Columbia Univ., New York, N.Y. 10032), \& TONNDORF, J. Tympanic membrane vibrations in cats studied by time-averaged holography. Journal of the Acoustical Society of America, 1972, 51, 1904-1920.

SCHUSTERMAN, R. J. (California State Coll., Hayward, Calif. 94542), BALLIET, R. F., \& NIXON, J. Underwater audiogram of the California sea lion by the conditioned vocalization technique. Journal of the Experimental Analysis of Behavior, 1972, 17, 339-350.

\section{Lower Senses}

BANDLER, R. J., JR. (Dept. of Psychiat., Yale Univ. Sch. of Med. \& Rsch. Facilities, Connecticut Mental Health Ctr., New Haven, Conn. 06519), \& CHI, C. C. Effects of olfactory bulb removal on aggression: A reevaluation. Physiology \& Behavior, 1972, 8, 207-211

CAMPBELL, H. J. (Dept. of Physiol., Inst. of Psychiat., De Crespigny Park, London SE5 8AF, England). Peripheral self-stimulation as a reward in fish, reptile and mammal. Physiology \& Behavior, 1972, 8, $637-640$.

KETTLEWELL, N. M. (Univ. of Montana, Missoula, Mont. 59801), WOOLSTON, D. C., \& BERGER, L. H. Effects of attenuating cutaneous afferent activity on a preestablished nictitating membrane response in rabbits. Journal of Comparative \& Physiological Psychology, 1972, 79, 299-306.

MASTERSON, F. A. (Univ, of Delaware, Newark, Del. 19711), WHIPPLE, M. C., \& BENNER, S. The role of proprioceptive stimulus change in the rat's avoidance learning. Psychonomic Science, 1972, 27, 260-262.

NEILL, W. H. (Honolulu Lab., Southwest Fisheries Service, Natl. Marine Fisheries Service, Honolulu, Hawaii 96812), MAGNUSON, J. J., 
\& CHIPMAN, G. G. Behavioral thermoregulation by fishes: A new experimental approach. Science, $1972,176,1443-1445$.

SIECK, M. H. (Univ. of California, Riverside, Calif. 92502). The role of the olfactory system in avoidance learning and activity. Physiology \& Behavior, 1972, 8, 705-710.

SMITH, D. V. (Univ. of Wyoming, Laramie, Wyo. 82070), \& FRANK, M. Cross adaptation between salts in the chorda tympani nerve of the rat. Physiology \& Behavior, 1972, 8, 213-220.
STARK, B. (Dept. of Biol., Yale Univ., New Haven, Conn. 06520), \& HAZLETT, B. A. Effects of olfactory experience on aggression in Mus musculus and Peromyscus maniculatus. Behavioral Biology, 1972, 7, 265-269.

ZAHORIK, D. M. (Univ. of Illinois, Champaign, Ill. 61820). Conditioned physiological changes associated with learned aversions to tastes paired with thiamine deficiency in the rat. Journal of Comparative \& Physiological Psychology, 1972, 79, 189-200.

\section{PHYSIOLOGICAL PSYCHOLOGY}

\section{BRAIN FUNCTIONS}

BATUEV, A. S. (Lab. of Physiol. of Motor Analyser, A. A. Ukhtomsky Physiol. Inst., Leningrad State Univ., Leningrad, USSR), \& PIROGOV, A. A. Investigation of the integrative functions of the motor analyser. Activitas Nervosa Superior, 1972, 14, 75-79.

BEST, P. J. (Univ. of Virginia, Charlottesville, Va. 22901). Effects of shock intensity on transfer of shock avoidance under unilateral spreading depression. Physiology \& Behavior, 1972, 8, 279-282.

DEADWYLER, S. A. (Dept. of Psychobiol, Univ. of California, Irvine, Calif. 92664), MONTGOMERY, D., \& WYERS, E. J. Passive avoidance and carbachol excitation of the caudate nucleus. Physiology \& Behavior, 1972, 8, 631-635.

DOOLITTLE, J. H. (Sacramento State Coll., Sacramento, Calif. 95819). The role of anterior ganglia in phototaxis and thigmotaxis in the earthworm. Psychonomic Science, $1972,27,151-152$.

WEST, R. W. (Biol. Labs., Harvard Univ., Cambridge, Mass. 02138), \& GREENOUGH, W. T. Effect of environmental complexity on cortical synapses of rats: Preliminary results. Behavioral Biology, 1972, 7, 279-284.

\section{Lesions}

ALLEN, J. D. (Univ. of Georgia, Athens, Ga. 30601), MITCHAM, J. C., \& BYRD, J. I. Effects of caudate lesions on the acquisition and retention of Sidman avoidance in the rat. Psychonomic Science, 1972, 27, 157-160.

BANDLER, R. J., JR. (Dept. of Psychiat., Yale Univ. Sch. of Med. \& Rsch. Facilities, Connecticut Mental Health Ctr., New Haven, Conn. 06519), \& CHI, C. C. Effects of olfactory bulb removal on aggression: A reevaluation.
Physiology \& Behavior, 1972, 8, 207-211.

DIVAC, I. (Inst. of Neurophysiol., Juliane Maries Vej 36, Copenhagen $\emptyset$, Denmark). Delayed alternation in cats with lesions of the prefrontal cortex and the caudate nucleus. Physiology \& Behavior, 1972, 8, 519-522.

FRIED, P. A. (Carleton Univ., Ottawa, Ont., Canada). The effect of differential hippocampal lesions and pre- and postoperative training on extinction. Canadian Journal of Psychology, 1972, 26, 61-70.

GREENSTEIN, S. (Herbert M. Singer Lab. of Neurosci. \& Addictive Diseases, Bernstein Inst., Beth Israel Med. Ctr., 10 Nathan D. Perlman PI., New York, N.Y. 10003), \& GLICK, S. D. A simple procedure for making stereotaxic lesions in the mouse. Physiology \& Behavior, 1972, 8, 781-782.

HENKE, P. G. (Muskingum Coll., New Concord, Ohio 43762), ALLEN, J. D., \& DAVISON, C. Effect of lesions in the amygdala on behavioral contrast. Physiology \& Behavior, 1972, 8, 173-176.

HOLDSTOCK, T. L. (Univ. of the Witwatersrand, Johannesburg, South Africa). Dissociation of function within the hippocampus. Physiology \& Behavior, 1972, 8, 659-667.

HOWZE, M. A. (Louisiana State Univ., Baton Rouge, La. 70803), \& THOMPSON, R. Disconnecting occipitoreticular projections: Amnestic effects on a visual habit in the rat. Psychonomic Science, 1972, 27, 143-145.

LYNCH, G. (Dept. of Psychobiol., Univ. of California, Irvine, Calif. 92650), \& CRAIN, B. Increased generalized activity following lesions of the caudal reticular formation. Physiology \& Behavior, $1972,8,747-750$.

MEANS, L. W., WOODRUFF, M. L. (Univ. of Florida, Gainesville, Fla.
32601), \& ISAACSON, R. L. The effect of a twenty-four hour intertrial interval on the acquisition of spatial discrimination by hippocampally damaged rats. Physiology \& Behavior, 1972, 8, 457-462.

RICHMAN, C. L. (Wake Forest Univ., Winston-Salem, N.C. 27109), GULKIN, R., \& KNOBLOCK, K. Effects of bulbectomization, strain, and gentling on emotionality and exploratory behavior in rats. Physiology \& Behavior, 1972, 8, 447-452.

RICKERT, E. J. (Univ. of Alabama, Birmingham, Ala. 35233), \& BENNETT, T. L. Performance of hippocampectomized rats on discontinuous negatively correlated reward. Behavioral Biology, 1972, 7, 375-382.

SCHMALTZ, L. W. (Univ, of Wisconsin, Madison, Wis. 53706), \& THEIOS, J. Acquisition and extinction of a classically conditioned response in hippocampectomized rabbits (Oryctolagus cuniculus). Journal of Comparative \& Physiological Psychology, 1972, 79, 328-333.

THOMPSON, R. (Louisiana State Univ., Baton Rouge, La. 70803), \& CRADDOCK, S. N., JR. Lateral cerebral peduncle lesions: Amnestic effects on a visual habit in the rat. Psychonomic Science, 1972, 27, 140-142.

THORNE, B. M. (Mississippi State Univ., State College, Miss. 39762). Brain lesions and affective behavior in primates: A selected review. Journal of General Psychology, $1972,86,153-162$.

THORNE, B. M. (Mississippi State Univ., State College, Miss. 39762). The red nucleus and olfactory discrimination in the rat. Journal of General Psychology, 1972, 86, 225-229.

WOODRUFF, M. L. (Univ, of Florida, Gainesville, Fla. 32601 ), SCHNEIDERMAN, B., \& ISAACSON, R. L. Impaired acquisition of a simultaneous brightness discrimination by cortically and hippocampally lesioned rats. Psychonomic Science, 1972, 27, 269-271.

\section{Cortex}

COOPER, R. M. (Univ. of Calgary, Calgary, Alta., Canada), BLOCHERT, K. P., GILLESPIE, L. A., \& MILLER, L. G. Translucent occluders and lesions of posterior neocortex in the rat. Physiology \& Behavior, 1972, 8, 693-697.

DELACOUR, J. (Centre d'Etudes de Physiologie nerveuse du C.N.R.S., Départment de Psychophysiologie, 4, ave. Gordon-Bennett, 75-Paris 
16e, France), LIBOUBAN, S.; \& McNEIL, M. Premotor cortex and instrumental behavior in monkeys. Physiology \& Behavior, 1972, 8, 299-305.

GAZZANIGA, M. S. (New York Univ., New York, N.Y. 10003). One brain-two minds? American Scientist, 1972, 60, 311-317.

GLICK, S. D. (Herbert M. Singer Lab. of Neurosci. \& Addictive Diseases, Beth Israel Med. Ctr., New York, N.Y. 10003), \& ZIMMERBERG, B. Comparative recovery following simultaneous- and successive-stage frontal brain damage in mice. Journal of Comparative \& Physiological Psychology, 1972, 79, 481-487.

MANNING, F. J. (Dept. of Exptl. Psychol., Div. of Neuropsychiat., Walter Reed Army Inst. of Rsch., Walter Reed Army Med. Ctr., Washington, D.C. 20012). Serial reversal learning by monkeys with inferotemporal or foveal prestriate lesions. Physiology \& Behavior, 1972, 8, 177-181.

WILCOVE, W. G. (Indiana Univ., Bloomington, Ind. 47401), \& VANCE, $W$. B. The effects of olfactory and frontal pole lesions on the drinking response to hypertonic loading in rats. Psychonomic Science, 1972, 27, 295-298.

GRAY, J. A. (Dept. of Exptl. Psychol, Univ. of Oxford, Oxford, England), QUINTÃO, L., \& ARAUJO-SILVA, M. T. The partial reinforcement extinction effect in rats with medial septal lesions. Physiology \& Behavior, 1972, 8, 491-496.

HOLLOWAY, F. A. (Dept. of Psychiat. \& Behav. Sci., Univ. of Oklahoma Health Sci. Ctr., Oklahoma City, Okla. 73190). Effects of septal chemical injections on asymptotic avoidance performance in cats. Physiology \& Behavior, 1972, 8, 463-469.

MICZEK, K. A., KELSEY, J. E., \& GROSSMAN, S. P. (Univ. of Chicago, Chicago, Ill. 60637). Time course of effects of septal lesions on avoidance, response suppression, and reactivity to shock. Journal of Comparative \& Physiological Psychology, 1972, 79, 318-327.

SCHWARTZBAUM, J. S. (Univ. of Rochester, Rochester, N.Y. 14627), DiLORENZO, P. M., MELLO, W. F., \& KREINICK, C. J. Further evidence of dissociation between reactivity and visual evoked response following septal lesions in rats. Journal of Comparative \& Physiological Psychology, 1972, 80, 143-149.

SCHWARTZBAUM, J. S. (Univ. of
Rochester, Rochester, N.Y. 14627), KREINICK, C. J., \& LEVINE, M. S. Behavioral reactivity and visual evoked potentials to photic stimuli following septal lesions in rats. Journal of Comparative \& Physiological Psychology, 1972, 80, 123-142.

S L O N A K E R, R. L , \& HOTHERSALL, D. (Lab. of Comparative \& Physiol. Psychol., Ohio State Univ., Columbus, Ohio 43212). Collateral behaviors and the DRL deficit of rats with septal lesions. Journal of Comparative \& Physiological Psychology, 1972, 80, 91-96.

SLOTNICK, B. M. (Lab. of Brain Evol. \& Behav., NIMH, Bethesda, Md. 20017), \& McMULLEN, M. F. Intraspecific fighting in albino mice with septal forebrain lesions. Physiology \& Behavior, 1972, 8, 333-337.

THOMAS, J. B. (Oberlin Coll., Oberlin, Ohio 44074). Stimulus perseveration and choice behavior in rats with septal lesions. Journal of Comparative \& Physiological Psychology, 1972, 80, 97-105.

THOMAS, J. B. (Oberlin Coll., Oberlin, Ohio 44074), \& VAN ATTA, L. Hyperirritability, lever-press avoidance, and septal lesions in the albino rat. Physiology \& Behavior, 1972, 8, 225-232.

VAN HOESEN, G. W. (Neurol. Unit, Harvard Med. Sch., Boston City Hosp., Boston, Mass. 02118), MacDOUGALL, J. M., \& MITCHELL, J. C. Discrimination of emitted behavior following septal area lesions in rats. Journal of Comparative \& Physiological Psychology, 1972, 80, 106-122.

\section{Hypothalamus}

BEATTY, W. W. (North Dakota State Univ., Fargo, N. Dak. 58102). Persistent depression of wood-gnawing following ventromedial hypothalamic lesions in the rat. Physiology \& Behavior, $1972,8,383-384$.

GOLD, R. M. (State Univ. of New York, Cortland, N.Y. 13045), \& PROULX, D. M. Bait-shyness acquisition is impaired by VMH lesions that produce obesity. Journal of Comparative \& Physiological Psychology, 1972, 79, 201-209.

GOLD, R. M. (State Univ. of New York, Cortland, N.Y. 13045), QUACKENBUSH, P. M., \& KAPATOS, G. Obesity following combination of rostrolateral to VMH cut and contralateral mammillary area lesion. Journal of Comparative \& Physiological Psychology, 1972, 79, 210-218.

KURTZ, R. G., ROZIN, P., \&
TEITELBAUM, P. (Univ. of Pennsylvania, Philadelphia, $\mathbf{P a}$. $\left.\begin{array}{lllll}1 & 9 & 1 & 0 & 4\end{array}\right)$. Ve ntromedial hypothalamic hyperphagia in the hypophysectomized weanling rat. Journal of Comparative \& Physiological Psychology, 1972, 80, 19-25.

MARKS, H. E. (Univ. of Georgia, Athens, Ga. 30601), \& MILLER, C. R. Development of hypothalamic obesity in the male golden hamster (Mesocricetus auratus) as a function of food preference. Psychonomic Science, 1972, 27, 263-265.

PAXINOS, G. (McGill Univ., Montreal, P.Q., Canada), \& BINDRA, D. Hypothalamic knife cuts: Effects on eating, drinking, irritability, aggression, and copulation in the male rat. Journal of Comparative \& Physiological Psychology, 1972, 79, 219-229.

\section{Stimulation}

LEATON, R. N. (Dartmouth Coll., Hanover, N.H. 03755), \& RECH, R. $\mathrm{H}$. Locomotor activity increases produced by intrahippocampal and intraseptal atropine in rats. Physiology \& Behavior, 1972, 8, 539-541.

LEVITT, R. A. (Southern Illinois Univ., Carbondale, Ill. 62901), \& O'HEARN, J. Y. Drinking elicited by cholinergic stimulation of CNS fibers. Physiology \& Behavior, 1972, 8, 641-644.

RUSSELL, M. J. (Stanford Rsch. Inst., Menlo Park, Calif. 94025 ), GODSEY, M. S., \& LYDELL, K. W. Omnitrode: A simple cannula for chemical and bipolar electrical stimulation. Physiology \& Behavior, 1972, 8, 773-775.

VOLKMAR, F. R. (Univ. of Illinois, Champaign, Ill. 61820), \& GREENOUGH, W. T. Rearing complexity affects branching of dendrites in the visual cortex of the rat. Science, $1972,176,1445-1447$.

\section{Electrical Stimulation}

GALIN, D. (Langley Porter Neuropsychiat. Inst., 401 Parnassus Ave., San Francisco, Calif. 94122), \& LACEY, J. I. Reaction time and heart rate response pattern: Effects of reticular stimulation in cats. Physiology \& Behavior, 1972, 8, 729-739.

GOLD, P. E. (Dept. of Psychobiol., Sch. of Biol. Sci., Univ. of California, Irvine, Calif. 92664), \& McGAUGH, J. L. Effect of recent footshock on brain seizures and behavioral convulsions induced by electrical stimulation of the brain. Behavioral Biology, 1972, 7, 421-426.

GRAY, J. A. (Dept. of Exptl. Psychol., Univ. of Oxford, Oxford, 
England). Effects of septal driving of the hippocampal theta rhythm on resistance to extinction. Physiology \& Behavior, 1972, 8, 481-490.

GRAY, J. A. (Dept. of Exptl. Psychol., Univ. of Oxford, Oxford, England), ARAUJO-SILVA, M. T., \& QUINTAO, L. Resistance to extinction after partial reinforcement training with blocking of the hippocampal theta rhythm by septal stimulation. Physiology \& Behavior, 1972, 8, 497-502.

NEWMAN, L. M. (Dept. of Pharmacol., Univ. of Michigan Med. Sch., Ann Arbor, Mich. 48104). Effects of cholinergic agonists and antagonists on self-stimulation behavior in the rat. Journal of Comparative \& Physiological Psychology, 1972, 79, 394-413.

SMITH, D. A. (Oberlin Coll., Oberlin, Ohio 44074). Increased perioral responsiveness: A possible explanation for the switching of behavior observed during lateral hy pothalamic stimulation. Physiology \& Behavior, 1972, 8, 617-621.

WHITE, S. D. $(800$ Irving Ave., Syracuse, N.Y. 13210), \& WAYNER, M. J. Lick rate during lateral hypothalamic electrical stimulation in the rat. Physiology \& Behavior, 1972, 8, 771-772.

ZORNETZER, S. F. (Dept. of Neurosci., Coll. of Med., Univ, of Florida, (Gainesville, Fla. 32601). Brain stimulation and retrograde amnesia in rats: A neuroanatomical approach. Physiology \& Behavior, $1972,8,239-244$

\section{Rewarding Slimulation}

CANTOR, M. B. (Univ. of Pennsylvania, Philadelphia, $\mathrm{Pa}$. 19104), \& LoLORDO, V. M. Reward value of brain stimulation is inversely related to uncertainty about its onset. Journal of Comparative \& Physiological Psychology, 1972, 79, 259-270.

DEUTSCH, J. A. (Univ. of California, San Diego, La Jolla, Calif. 92037), \& HAWKINS, R. D. Adaptation as a cause of apparent aversiveness of prolonged rewarding brain stimulation. Behavioral Biology, $1972,7,285-290$.

HUSTON, J. P. (Inst. of Pharmacol., Univ. of Zürich, Gloriastrasse 32, Zürich, Switzerland), MILLS, A. W., \& HUSTON, R. Strength-duration function of hypothalamic self-stimulation. Behavioral Biology, $1972,7,383-390$.

NAKAJIMA, S. (Dalhousie Univ., Halifax, N.S., Canada). Effects of intracranial chemical injections upon self-stimulation in the rat.
Physiology \& Behavior, 1972, 8, 741-746.

SADOWSKI, B. (Exptl. \& Clin. Med. Rsch. Ctr., Iab. of Applied Physiol., Polish Acad. of Sci., Warsaw 36, Poland). Intracranial self-stimulation patterns in dogs. Physiology \& Behavior, 1972, 8, 189-193.

WEST, G. L. (Univ. of Oklahoma Med. Ctr., Oklahoma City, Okla. 73104), \& REID, L. D. Extinction after water and intracranial reinforcement Psychonomic Science, 1972, 27, 137-139.

WETZEL, M. C. (Univ. of Arizona, Tucson, Ariz. 85721). New evidence concerning refractory period in self-stimulation neurons. Physiology \& Behavior, 1972, 8, 397-402.

\section{Electroconvulsive Shock}

GOLUB, M. S. (Behav. Pharmacol. Labs., Boston Univ. Med. Sch., 80 E. Concord, Boston, Mass. 02118), CHEAL, M. L., \& DAVIS, R. E. Effects of electroconvulsive shock and puromycin on operant responding in goldfish. Physiology \& Behavior, 1972, 8, 573.578.

MILLER, R. R. (Brooklyn Coll. of CUNY, Brooklyn, N.Y. 11210), \& SPRINGER, A. D. Induced recovery of memory in rats following electroconvulsive shock. Physiology \& Behavior, 1972, 8, 645-651.

MILLER, R. R. (Brooklyn Coll. of CUNY, Brooklyn, N.Y. 11210), \& SPRINGER, A. D. Recovery from amnesia following transcorneal electroconvulsive shock. Psychonomic Science, 1972, 28, 7-9.

SPEVACK, A. A. (Virginia Polytech. Inst. \& State Univ., Blacksburg, Va. 24061). The permanence of ECS effects in a one-trial discriminated avoidance paradigm. Psychonomic Science, 1972, 28, 41-43.

\section{Electrical Activity}

DENMAN, P. M., MILLER, L. H., SANDMAN, C. A., SCHALLY, A. V., \& KASTIN, A. J. (Endocrinol. Sec., VA Hosp., 1601 Perdido St., New Orleans, La. 70146). Electrophysiological correlates of melanocyte-stimulating hormone activity in the frog. Journal of Comparative \& Physiological Psychology, 1972, 80, 59-65.

GROVES, P. M. (Univ. of Colorado, Boulder, Colo. 80302), \& LYNCH, G. S. Mechanisms of habituation in the brain stem. Psychological Review, 1972, 79, 237-244.

\section{$E E G$}

DONCHIN, E. (Univ. of Illinois, Champaign, Ill. 61820 ), GERBRANDT, L. A., LEIFER, L., \& TUCKER, $\mathrm{L}$. Is the contingent negative variation contingent on a motor response? Psychophysiology, $1972,9,178.188$.

FLORIO, V. (Laboratori di Chimica Terapeutica, Istituto Superiore di Sanità, Rome, Italy), FUENTES, J. A., ZIEGLER, H., \& LONGO, V. G. EEG and behavioral effects in animals of some amphetamine derivatives with hallucinogenic properties. Behavioral Biology, 1972, 7, 401-414.

IWAHARA, S. (Tokyo Univ. of Ed., Tokyo, Japan), OISHI, H., YAMAZAKI, S., \& SAKAI, K. Effects of chlordiazepoxide upon spontaneous alternation and the hippocampal electrical activity in white rats. Psychopharmacologia (Berlin), 1972, 24, 496-507.

LANDFIELD, P. W. (Lab. of Chem. Neurobiol., Sch. of Med., Univ. of North Carolina, Chapel Hill, N.C. 27514), \& McGAUGH, J. L. Effects of electroconvulsive shock and brain stimulation on EEG cortical theta rhythms in rats. Behavioral Biology, 1972, 7, 271-278.

MULHOLLAND, T. B. (Percep. Lab., VA Hosp., Bedford, Mass. 01730). Feedback electroencephalography II. Activitas Nervosa Superior, $1971,13,266-277$.

STEVENS, J. R. (Dept. of Psychiat., Massachusetts Gen. Hosp., Boston, Mass. 02114), LONSBURY, G., \& GOEL, S. Electroencephalographic spectra and reaction time in disorders of higher nervous function. Science, 1972, 176 , 1346-1349.

ZORNETZER, S. F. (Dept. of Neurosci., Sch. of Med., Univ. of Florida, Gainesville, Fla. 32601), \& $M$ c G A U G H , J . L . Electrophysiological 'correlates of frontal cortex-induced retrograde amnesia in rats. Physiology \& Behavior, 1972, 8, 233-238.

\section{Evoked Potentials}

BROGAN, F. A. (Vestibular Lab. USAF Sch. of Aerospace Med., Aerospace Med. Div. (AFSC), Brooks AFB, San Antonio, Tex. 78235), \& WOLFE, J. W. A method of averaging evoked potentials that precede saccadic (rapid) eye movements. Physiology \& Behavior, $1972,8,557-560$.

BUTLER, R. A. (Sec. of Otolaryngol., Univ. of Chicago, Chieago, Ill. 60637). The auditory evoked response to stimuli producing period'icit y pitch. Psychophysiology, 1972, 9, 233-237.

JENNESS, D. (Soc. Sci. Rsch. Council, 230 Park Ave., New York, N.Y. 10017). Auditory evoked-response differentiation with discrimination learning in humans. Journal of 
Comparative \& Physiological Psychology, 1972, 80, 75-90.

MacDONNELL, M. F. (Ctr. of Alcohol Studies, Rutgers Univ., New Brunswick, N.J. 08903), \& FESSOCK, L. Some effects of ethanol, amphetamine, disulfiram and $p \cdot C P A$ on seizing of prey in feline predatory attach and on associated motor pathways. Quarterly Journal of Studies on Alcohol, 1972, 33, 437-450.

OHMAN, A., KAYE, J. J., \& LADER, M. (Inst. of Psychiat., Univ. of London, Denmark Hill, London, S.E. 5, England). Regular interstimulus interval as a critical determinant of short-term "habituation" of the auditory averaged evoked response. Psychonomic Science, 1972, 27, 275-278.

PHILLIPS, D. S. (Depts. of Med. Psychol. \& Psychiat., Univ. of Oregon Med. Sch., Portland, Oreg. 97201 ), DENNEY, D. D. ROBERTSON, R. T., HICKS, L. H., \& THOMPSON, R. F. Cortical projections of ascending nonspecific systems. Physiology \& Behavior, 1972, 8, 269-277.

SCHWARTZBAUM, J. S. (Univ. of Rochester, Rochester, N.Y. 14627), DiLORENZO, P. M., MELLO, W. F., \& KREINICK, C. J. Further evidence of dissociation between reactivity and visual evoked response following septal lesions in rats. Journal of Comparative \& Physiological Psychology, 1972, 80, 143-149.

SCHWARTZBAUM, J. S. (Univ. of Rochester, Rochester, N.Y. 14627), KREINICK, C. J., \& LEVINE, M. S. Behavioral reactivity and visual evoked potentials to photic stimuli following septal lesions in rats. Journal of Comparative \& Physiological Psychology, 1972, 80, 123-142.

TEYLER, T. J. (Dept. of Psychobiol., Univ. of California Irvine, Calif. 92664), ROEMER, R. A., \& THOMPSON, R. F. Habituation of the pyramidal response in unanesthetized cat. Physiology \& Behavior, 1972, 8, 201-205.

\section{Nerve Impulses}

CAMPOS, G. B. (Neurol. Dept., Fed. Univ. of Minas Gerais, Belo Horizonte, MG, Brazil), JOHNSON, J. I., JR., \& BOMBARDIERI, R. A., JR. Organization of tactile thalamus and related behavior in the agouti, Dasyprocta aguti. Physiology \& Behavior, 1972, 8, 553-556.

GROVES, P. M. (Univ. of Colorado, Boulder, Colo. 80302), MILLER, S. W., \& PARKER, M. V. Habituation and sensitization of neuronal activity in the reticular formation of the rat. Physiology \& Behavior, 1972, 8, 589-593.

TEYLER, T. J. (Dept. of Psychobiol., Univ. of Calif. Irvine, Calif. 92664), SHAW, C., \& THOMPSON, R. F. Unit responses to moving visual stimuli in the motor cortex of the cat. Science, 1972, 176, 811-813.

\section{Metabolism}

KOTTLER, P. D. (Reg. Prim. Rsch. Ctr., Univ, of Wisconsin, Madison, Wis. 53706), BOWMAN, R. E., \& HAASCH, W. D. RNA metabolism in the rat brain during learning following intravenous and intraventricular injections of ${ }^{3}$ H-cytidine. Physiology \& Behavior, 1972, 8, 291-297.

NOVÁKOVÁ, V. (Inst. of Physiol., Czechoslovak Acad. of Sci., Prague, Czechoslovakia), SANDRITTER, W., \& SCHLUETER, G. Ribonucleic acid and learning in old rats. Activitas Nervosa Superior, 1971, 13, 253-258.

ROSECRANS, J. A. (Dept. of Ph a r m a c l., Virginia Commonwealth Univ., Med. Coll. of Virginia, Richmond, Va. 23219), \& SCHECHTER, M. D. Brain 5-hydroxytryptamine correlates of behavior in rats: Strain and sex variability. Physiology \& Behavior, $1972,8,503-510$.

SCHREIBER, R. A. (Dept. of Biochem., Med. Univ. of South Carolina, Charleston, S.C. 29401), \& SCHLESINGER, K. Circadian rhythms and seizure susceptibility: Effects of manipulations of light cycles on susceptibility to audiogenic seizues and on levels of 5 -hydroxytryptamine and norepinephrine in brain. Physiology \& Behavior, 1972, 8, 699-703.

\section{PHYSIOLOGICAL EFFECTS}

BELL, R. W. (Northern Illinois Univ., DeKalb, Ill. 60115), \& ROLSTEN, C. Developmental effects of variable population density and dietary protein sufficiency upon morphology, neurochemistry, and behavior in the rat. Psychonomic Science, 1972, 27, 149-150.

FEIGLEY, D. A., PARSONS, P. J. HAMILTON, L. W., \& SPEAR, N. E. (Rutgers-The State Univ., New Brunswick, N.J. 08903 ). Development of habituation to novel environments in the rat. Journal of Comparative \& Physiological Psychology, 1972, 79, 443-452.

HOLLOWAY, F. A. (Whiteman House for Mental Rsch., 607 N.E. 15th St., Oklahoma City, Okla. 73104), \& PARSONS, O. A. Physiological concomitants of reaction time performance in normal and brain-damaged subjects.
Psychophysiology, 1972, 9, 189-198.

LAŚT́OVKA, M. (Phoniatric Lab., Med. Faculty, Charles Univ., Prague, Czechoslovakia). The influence of emotion on the monosynaptic spinal cord reflex activity in man. Activitas Nervosa Superior, 1972, $14,13-17$.

PARE, W. P. (Pavlovian Rsch. Lab., VA Hosp., Perry Point, Md. 21902). Conditioning and avoidance responding ' effects on gastric secretion in the rat with chronic fistula. Journal of Comparative \& Physiological Psychology, 1972, 80, 150-162.

PRICE, K. P. (State Univ. of New York, Stony Brook, N.Y. 11790). Predictable and unpredictable shock: Their pathological effects on restrained and unrestrained rats. Psychological Reports, 1972, 30, 419-426.

TIMMONS, B. (Langley Porter Neuropsychiat. Inst., San Francisco, Calif, 94122), SALAMY, J., KAMIYA, J., \& GIRTON, D. Abdominal-thoracic respiratory movements and levels of arousal. Psychonomic Science, 1972, 27, 173-175.

\section{Biochemical Effects}

FABRE, L: F., JR. (Sec. of Neuroendocrinol., Taxas Rsch. Inst. of Mental Sci., Houston, Tex. 77025 ), FARMER, R. W., PELLIZZARI, E. D., \& FARRELL, G. Aldosterone secretion in pentobarbital-anest hetized ethanol-infused dogs. Quarterly Journal of Studies on Alcohol, $1972,33,476 \cdot 484$.

MAYER, A. J. (Univ. of Texas, Arlington, Tex. 76010), \& COX, V. C. Serum osmolality and meal initiation in food and water-deprived rats. Behavioral Biology, 1972, 7, 435-439.

McCUTCHEON, B. (State Univ, of New York, Albany, N.Y. 12203), \& LEVY, C. Relationship between $\mathrm{NaCl}$ rewarded bar-pressing and duration of sodium deficiency. Physiology \& Behavior, 1972, 8, 761-763.

THORNTON, L. W. (Univ. of Wyoming, Laramie, Wyo. 82070), \& WETTER, B. D. Blood osmolality changes in sheep at satiety. Psychonomic Science, 1972, 27, 155-156.

\section{Hormonal Effects}

BRAIN, P. F. (Dept. of Zool., Univ. Coll. of Swansea, Glamorganshire, Wales). Effects of isolation/grouping on endocrine function and fighting behavior in male and female golden hamsters (Mesocricetus auratus 
Waterhouse). Behavioral Biology, 1972, 7, 349-357.

DENMAN, P. M., MILLER, L. H., SANDMAN, C. A., SCHALLY, A. V., \& KASTIN, A. J. (Endocrinol. Sec., VA Hosp., 1601 Perdido St., $\mathrm{New}$ Orleans, La. 70146). Electrophysiological correlates of melanocyte-stimulating hormone activity in the frog. Journal of Comparative \& Physiological Psychology, 1972, 80, 59-65.

JOFFE, J. M. (Univ. of Vermont, Burlington, Vt. 05401 ), MILKOVIĆ, K., \& LEVINE, $S$. Effects of changes in maternal pituitary-adrenal function on behavior of rat offspring. Physiology \& Behavior, 1972, 8, 425-430.

KLEIN, S. B. (Old Dominion Univ., Norfolk, Va. 23508 ). Adrenal-pituitary influence in reactivation of avoidance-learning memory in the rat after intermediate intervals. Journal of Comparative \& Physiological Psychology, 1972, 79, 341-359.

KOOPMANS, H. S. (Univ, of California, San Diego, La Jolla, Calif. 92037), DEUTSCH, J. A., \& BRANSON, P. J. The effect of cholecystokinin-pancreozymin on hunger and thirst in mice. Behavioral Biology, 1972, 7, 441-444.

LESHNER, A. I. (Bucknell Univ., Lew isburg, $\quad P a, \quad 17837), \quad \&$ CANDLAND, D. K. Endocrine effects of grouping and dominance rank in squirrel monkeys. Physiology \& Behavior, 1972, 8, 441-445.

PAGANO, R. R. (Univ. of Washington, Seattle, Wash. 98195), \& LOVELY, R. H. Diurnal cycle and ACTH facilitation of shuttlebox avoidance. Physiology \& Behavior, 1972, 8, 721-723.

SANDMAN, C. A., MILLER, L. H., KASTIN, A. J. (Endocrinol. Sec., VA Hosp., 1601 Perdido St., New Orleans, La. 70146), \& SCHALLY, A. V. Neuroendocrine influence on attention and memory. Journal of Comparative \& Physiological Psychology, 1972, 80, 54-58.

STEPHAN, F. K. (Univ. of California, Berkeley, Calif. 94720), \& ZUCKER, I. Rat drinking rhythms: Central visual pathways and endocrine factors mediating responsiveness to environmental illumination. Physiology \& Behavior, 1972, 8, 315-326.

VALE, J. R. (Univ. of California, Berkeley, Calif. 94720), RAY, D., \& VALE, C. A. The interaction of genotype and exogenous neonatal androgen: Agonistic behavior in female mice. Behavioral Biology, $1972,7,321-334$.
Adrenal Gland

DAVIS, M. (Yale Univ. Sch. of Med., New Haven, Conn. 06519), \& ZOLOVICK, A. J. Habituation of the startle response in adrenalectomized rats. Physiology \& Behavior, 1972, 8, 579-584.

EVERITT, B. J. (Dept. of Anat., Univ. of Birmingham, Birmingham B15 2TJ, England), HERBERT, J., \& HAMER, J. D. Sexual receptivity of bilaterally adrenalectomised female rhesus monkeys. Physiology \& Behavior, 1972, 8, 409-415.

HARDING, C. F., \& LESHNER, A. I. (Bucknell Univ., Lewisburg, Pa. 17837). The effects of adrenalectomy on the aggressiveness of differently housed mice. Physiology \& Behavior, 1972, 8, 437-440.

\section{Gonads}

LEE, C. T. (Brooklyn Coll. of CUNY, Brooklyn, N.Y. 11210), \& BRAKE, S. C. Reaction of male mouse fighters to male castrates treated with testosterone propionate or oil. Psychonomic Science, 1972, 27, 287-288.

PAYNE, A. P. (Dept. of Anat., Med. Sch., Univ. of Birmingham, Birmingham B15 2TJ, England), \& SWANSON, H. H. The effect of sex hormones on the agonistic behavior of the male golden hamster (Mesocricetus auratus Waterhouse). Physiology \& Behavior, 1972, 8, 687-691.

POWERS, J. B. (Neurosci. Lab., Univ. of Michigan, Ann Arbor, Mich. 48104), \& VALENSTEIN, E. S. Individual differences in sexual responsiveness to estrogen and progesterone in ovariectomized rats. Physiology \& Behavior, 1972, 8, 673-676.

WADE, G. N. (Inst. of Animal Behav., Rutgers Univ., Newark, N.J. 07102). Gonadal hormones and behavioral regulation of body weight. Physiology \& Behavior, $1972,8,523-534$.

WHALEN, R. E. (Dept. of Psychobiol., Univ. of California, Irvine, Calif. 92664), BATTIE, C., \& LUTTGE, W. G. Anti-estrogen inhibition of androgen induced sexual receptivity in rats. Behavioral Biology, 1972, 7, 311-320.

WORK, M. S. (Sacramento State Coll., Sacramento, Calif. 95819), \& ROGERS, $H$. Effect of estrogen level on food-seeking dominance among male rats. Journal of Comparative \& Physiological Psychology, 1972, 79, 414-418.

\section{Drug Effects}

AVIS, H. H. (Psychol. Sec., Biomed. Lab., Edgewood Arsenal, Md. 21010). Hippocampal injections of
$\mathrm{KCl}$ and shock-induced bradycardia in the rat. Psychonomic Science, $1972,27,283-284$.

CAMERON, O. G., \& APPEL, J. B. (Dept. of Psychiat., Univ. of Chicago, Chicago, Ill. 60637) Generalization of LSD-induced conditioned suppression. Psychonomic Science, 1972, 27, 302-304.

DRU, D. (Huntington Inst. of Applied Med. 'Rsch., Pasadena, Calif. 91100), AGNEW, W. F., \& GREENE, E. Effects of tellurium ingestion on learning capacity of the rat. Psychopharmacologia (Berlin), 1972, 24, 508-515.

GROTA, L. J. (Univ. of Rochester Sch. of Med. \& Dent., Rochester, N.Y. 14642), \& ADER, R. Effects of early experience with electric shock and dexamethasone on avoidance conditioning at adulthood. Psychonomic Science, $1972,28,10-12$.

HOUSER, V. P. (VA Hosp., Perry Point, Md. 21902), \& PARE, W. P. A method for determining the aversive threshold in the rat using repeated measures: Tests with morphine sulfate. Behavior Research Methods \& Instrumentation, $1972,4,135-137$.

KOTTLER, P. D. (Reg. Prim. Rsch. Ctr., Univ. of Wisconsin, Madison, Wis. 53706), BOWMAN, R. E., \& HAASCH, W. D. RNA metabolism in the rat brain during learning following intravenous and intraventricular injections of ${ }^{3} \mathrm{H}$-cytidine. Physiology \& Behavior, 1972, 8, 291-297.

MacDONNELL, M. F. (Ctr. of Alcohol Studies, Rutgers Univ., New Brunswick, N.J. 08903), \& FESSOCK, L. Some effects of ethanol, amphetamine, disulfiram and $p$-CPA on seizing of prey in feline predatory attack and on associated motor pathways. Quarterly Journal of Studies on Alcohol, 1972, 33, 437-450.

NAKAJIMA, S. (Dalhousie Univ. Halifax, N.S., Canada). Effects of intracranial chemical injections upon self-stimulation in the rat. Physiology \& Behavior, 1972, 8, 741.746.

ROLLS, B. J. (Dept. of Exptl. Psychol., Univ. of Oxford, Oxford, OXI 3PS, England), \& JONES, B. P. Cessation of drinking following intracranial injections of angiotensin in the rat. Journal of Comparative \& Physiological Psychology, 1972, 80, 26-29.

ROSIĆ, N. (Dept. of Pharmacol., Med. Faculty, Univ. of Belgrade, Belgrade, Yugoslavia), \& M I LOSEVIC, M. Two-way (shuttle-box) avoidance in rats after paraoxon treatment. Activitas 
Nervosa Superior, 1971, 13, 241-245.

RUSSEK, M. (Escuela Nacional de Ciencias Biológicas, Instituto Ploitécnico Nacional, México, 17 D.F., Mexico), \& STEVENSON, J. A. F. Correlation between the effects of several substances on food intake and on the hepatic concentration of reducing sugars. Physiology \& Behavior, 1972, 8, 245-249.

SARA, S. J. (Ctr. of Exptl. \& Comparative Psychol., Univ. of Louvain, Brussels, Belgium), \& LEFEVRE, D. Hypoxia-induced amnesia in one-trial learning and pharmacological protection by Piracetam. Psychopharmacologia (Berlin), 1972, 25, 32-40.

SPENCER, J. (Dept. of Psychiat. \& Behav. Sci., Univ. of Oklahoma Health Sci. Ctr., 800 N.E. 13, P.O. Box 26901, Oklahoma City, Okla. 73190), \& HOLLOWAY, F. A. Differentiation between carbachol a $n$ d s e r ine during deprivation-induced drinking in the rat. Psychonomic Science, 1972, 28, 16-18.

TART, C. T. (Univ. of California, Davis, Calif. 95616). States of consciousness and state-specific sciences. Science, 1972, 176 , 1203-1210.

\section{Alcohol}

FABRE, L. F., JR. (Sec. of Neuroendocrinol., Texas Rsch. Inst. of Mental Sci., Houston, Tex. 77025 ), FARMER, R. W., PELLIZZARI, E. D., \& FARRELL, G. Aldosterone secretion in pentobarbital-anest hetized ethanol-infused dogs. Quarterly Journal of Studies on Alcohol, $1972,33,476-484$.

M Y ER S, R. D. ( Lab . of Neuropsychol., Purdue Univ., Lafayette, Ind. 47907), \& TYTELL, M. Volitional consumption of flavored ethanol solution by rats: The - effects of pCPA, and the absence of tolerance. Physiology \& Behavior, 1972, 8, 403-408.

MYERS, R. D. (Lab. of Neuropsychol., Purdue Univ., Lafayette, Ind. 47907), VEALE, W. L., \& YAKSH, T. L. Preference for ethanol in the rhesus monkey following chronic infusion of ethanol into the cerebral ventricles. Physiology \& Behavior, 1972, 8, 431-435.

SHUNTICH, R. J. (Kent State Univ., Kent, Ohio 44240), \& TAYLOR, S. $P$. The effects of alcohol on human physical aggression. Journal of Experimental Research in Personality, 1972, 6, 34-38.

\section{Amines}

FIBIGER, H. C. (Div. of Neurol. Sci.,
Dept. of Psychiat., Univ. of British Columbia, Vancouver, B.C., Canada), MERTZ, P. H., \& CAMPBELL, B. A. The effect of para-chlorophenylalanine on aversion thresholds and reactivity to foot shock. Physiology \& Behavior, 1972, 8, 259-263.

GEYER, M. A. (Dept. of Psychiat., Sch. of Med., Univ. of California, San Diego, La Jolla, Calif, 92037), SEGAL, D. S., \& MANDELL, A. J. Effect of intraventricular infusion of dopamine and norepinephrine on motor activity. Physiology \& Behavior, 1972, 8, 653-658.

GLICK, S. D, (Herbert M. Singer Lab. of Neurosci. \& Addictive Diseases, Bernstein Inst., Beth Israel Med. Ctr., 307 2nd Ave., New York, N.Y. $10003), \&$ ZIMMERBERG, B. Amnesic effects of scopolamine. Behavioral Biology, 1972, 7, 245-254.

GOLUB, M. S. (Behav. Pharmacol. Labs., Boston Univ. Med. Sch., 80 E. Concord, Boston, Mass. 02118), CHEAL, M. L., \& DAVIS, R. E. Effects of electroconvulsive shock and puromycin on operant responding in goldfish. Physiology \& Behavior, 1972, 8, 573-578.

GRIFFITHS, W. J. (Dept. of Psychiat., Univ. of Oklahoma Med. Ctr., Oklahoma City, Okla. 73104), LESTER, B. K., COULTER, J. D., \& WILLIAMS, H. L. Tryptophan and sleep in young adults. Psychophysiology, 1972, 9, 345-356.

HARTMANN, E. (Sleep \& Dream Lab., 591 Morton St., Boston, Mass. 01545 ), \& STERN, W. C. Desynchronized sleep deprivation: Learning deficit and its reversal by increased catecholamines. Physiology \& Behavior, 1972, 8, 585-587.

HASSELAGER, E. (Sct. Hans Hosp., Dept. E, 4000 Roskilde, Denmark ), ROLINSKI, Z., \& RANDRUP, A. Specific antagonism by dopamine inhibitors of items of amphetamine induced aggressive behavior. Psychopharmacologia (Berlin), 1972, 24, 485-495.

HUTTON, R. S. (Univ. of Washington, Seattle, Wash. 98105), \& STEVENS, J. L. Scopolamine effects on forced exercise to exhaustion. Psychonomic Science, 1972, 27, 171-172.

NANCE, D. M. (Worcester Fdtn. for Exptl. Biol., 222 Maple Ave., Shrewsbury, Mass. 01545), \& KILBEY, M. M. Self-selection of 5 - hydroxytryptophan in Dl-para-chlorophenylalanine treated rats. Physiology \& Behavior, 1972, 8, 545-547.

PAPPAS, B. A. (Carleton Univ., Ottawa, Ont., Canada), DiCARA, L. V., \& MILLER, N. E. Acute s y m p a t h e c t o m y by 6-hydroxydopamine in the adult rat: Effects on cardiovascular conditioning and fear retention. Journal of Comparative \& Physiological Psychology, 1972, 79, 230-236.

TITUS, H. E. (Muskingum Coll., New Concord, Ohio 43762), \& COSTANZO, D. J. Effects of puromycin on learning in the toad. Psychological Reports, 1972, 30, $627-630$.

TONGE, S. R. (Sch. of Pharmacy, The Polytechnic, Byrom St., Liverpool, England), \& LEONARD, B. E. Partial antagonism of the behavioural and neurochemical effects of phencyclidine by drugs affecting monoamine metabolism: Psychopharmacologia (Berlin), 1972, 24, 516-520.

VAN ABEELEN, J. (Genetics Lab. Univ. of Nijmegen, The Netherlands), GILISSEN, L., HANSSEN, T., \& LENDERS, A. Effects of intrahippocampal injections with methylscopolamine and neostigmine upon exploratory behaviour in two inbred mouse strains. Psychopharmacologia (Berlin), 1972, 24, 470-475.

WALLEN, $\mathrm{K}$. (Univ. of California, Berkeley, Calif. 94720 ), GOLDFOOT, D. A., JOSLYN, W. D., \& PARIS, C. A. Modification of behavjoral estrus in the guinea pig following intracranial cycloheximide. Physiology \& Behavior, 1972, 8, 221-223.

ZIEGLER, H. (Laboratori di Chimica Terapeutica, Istituto Superiore di Sanità, Rome, Italy), DEL BASSO, $P ., \&$ LONGO, V. G. Influence of $6 \cdot$ hydroxydopamine and of $\alpha$-methyl-p-tyrosine on the effects of some centrally acting agents. Physiology \& Behavior, 1972, 8, 391-396.

\section{Anesthetics}

BLACKBURN, J. G. (Med. Univ. of South Carolina, Charleston, S.C. 29401). Chloralose and food intake in rats. Physiology \& Behavior, 1972, 8, 791-792.

PORTER, A. L. (Psychobiol. Rsch. Lab., VA Hosp., Sepulveda, Calif. 91343). An analytical review of the effects of non-hydrogen-bonding anesthetics on memory processing. Behavioral Biology, 1972, 7, 291-309.

ROZIN, P. (Univ. of Pennsylvania, Philadelphia, Pa. 19104), \& REE, P. Long extension of effective CS-US interval by anesthesia between CS and US. Journal of Comparative \& Physiological Psychology, 1972, 80, 43-48.

\section{Neurotransmitters}

DEADWYLER, S. A. (Dept. of 
Psychobiol., Univ. of California, Irvine, Calif, 92664 ), MONTGOMERY, D., \& WYERS, E. J. Passive avoidance and carbachol excitation of the caudate nucleus. Physiology \& Behavior, 1972, 8, 631-635.

LEATON, R. N. (Dartmouth Coll., Hanover, N.H. 03755), \& RECH, R. H. Locomotor activity increases produced by intrahippocampal and intraseptal atropine in rats. Physiology \& Behavior, 1972, 8, 539-541.

LEVITT, R. A. (Southern Illinois Univ., Carbondale, Ill. 62901), \& O'HEARN, J. Y. Drinking elicited by cholinergic stimulation of CNS fibers. Physiology \& Behavior, 1972, 8, 641-644.

LEWIS, D. J. (Univ. of Southern California, Los Angeles, Calif. 90007), \& BREGMAN, N. J. The cholinergic system, amnesia and memory. Physiology \& Behavior, 1972, 8, 511-514.

NEWMAN, L. M. (Dept. of Pharmacol., Univ. of Michigan Med. Sch., Ann Arbor, Mich. 48104). Effects of cholinergic agonists and antagonists on self-stimulation behavior in the rat. Journal of Comparative \& Physiological Psychology, 1972, 79, 394-413.

OVERSTREET, D. H. (Dept. of Psychobiol., Univ. of California, Irvine, Calif. 92664), HADICK, D. G., \& RUSSELL, R. W. Effects of amphetamine and pilocarpine on eating behavior in rats with chronically low acetylcholinesterase levels. Behavioral Biology, 1972, 7, 217-226.

TERPSTRA, G. K. (Rudolf Magnus Inst. for Pharmacol., Med. Faculty, Univ. of Utrecht, Vondellaan 6, Utrecht, The Netherlands), \& SLANGEN, J. L. Central blockade of (methyl-)atropine on carbachol drinking: A dose-response study. Physiology \& Behavior, 1972, 8, 715-719.

VOGEL, J. R. (Squibb Inst. for Med. Rsch., New Brunswick, N.J. 08903), \& LEAF, R. C. Initiation of mouse killing in non-killer rats by repeated pilocarpine treatment. Physiology \& Behavior, 1972, 8, 421-424.

\section{Stimulants}

de ARAÚJO CARLINI, E. L. (Setor de Psicofarmacologia, Departamento de Bioquímica $\mathrm{e}$ Farmacologia, Escola Paulista de Medicina, Rua Botucatu, 862-04023, Sảo Paulo, Brazil), de LORENZO, R. M. T., \& de ALMEIDA, E. T. A suggested aversive effect in rats of posttrial administration of central nervous system stimulants. Behavioral Biology, 1972, 7, 391-400.
CROWLEY, T. P. (Univ. of Southern Mississippi, Hattiesburg, Miss. 39401), \& SISEMORE, D. A. The failure of methamphetamine hydrochloride to produce dissociation of an escape response. Psychonomic Science, 1972, 28, 50-52.

FLORIO, V. (Laboratori di Chimica Terapeutica, Istituto Superiore di Sanità, Rome, Italy), FUENTES, J. A., ZIEGLER, H., \& LONGO, V. G. EEG and behavioral effects in animals of some amphetamine derivatives with hallucinogenic properties. Behavioral Biology, 1972, 7, 401-414.

KIRKBY, R. J., BELL, D. S. (Psychiat. Rsch. Unit, Callan Park Hosp., Rozelle, N.S.W., Australia, 2039), \& PRESTON, A. C. The effects of methylamphetamine on stereotyped behaviour, activity, startle, and orienting responses. Psychopharmacologia (Berlin), $1972,25,41-48$.

KULKARNI, A. S. (Dept. of Pharmacol., Dow Human Health Rsch. Labs,, Zionsville, Ind. 46077). Selective increase in avoidance responding by methamphetamine in naive rats. Psychopharmacologia (Berlin), 1972, 24, 449-455.

LUTTGES, M. W. (Dept. of Aerospace Eng. Sci., Univ. of Colorado, Boulder, Colo. 80302), \& ANDRY, M. L. Convulsive activity in garter snakes. Behavioral Biology, 1972, 7, 227-243.

NIEMEGEERS, C. J. E. (Janssen Pharmaceutica, Rsch. Labs., B-2340 Beerse, Belgium), VERBRUGGEN, F. J., WAUQUUIER, A., \& JANSSEN, P. A. J. The influence of haloperidol and amphetamine on two different noise-escape situations in rats. Psychopharmacologia (Berlin), 1972, 25, 22-31.

\section{Tranquilizers}

BIANCHI, G. N. (Commonwealth Med. Fellow, Inst. of Psychiat., Denmark Hill, London, S.E.5, England), \& PHILLIPS, J. A comparative trial of doxepin and diazepam in anxiety states. Psychopharmacologia (Berlin), $1972,25,86-95$.

BLOOMFIELD, T. M. (York Univ., Downsview 463, Ont., Canada). Contrast and inhibition in discrimination learning by the pigeon: Analysis through drug i iects. Learning \& Motivation, $1972,3,162-178$.

HUGHES, R. N. (Univ. of Canterbury, Canterbury, New Zealand). Chlordiazepoxide modified exploration in rats. Psychopharmacologia (Berlin), 1972, 24, 462-469.

IWAHARA, S. (Tokyo Univ. of Ed.,
Tokyo, Japan), OISHI, H., YAMAZAKI, S., \& SAKA', K. Effects of chlordiazepoxide upon spontaneous alternation and the hippocampal electrical activity in white rats. Psychopharmacologia (Berlin), 1972, 24, 496-507.

MASKER, J. D. (Temple Univ., Philadelphia, Pa. 19122), \& HAMMOND, L. J. Disruption of a temporal discrimination by the minor transquilizer, oxazepam. Psychopharmacologia (Berlin), 1972, 25, 69-76.

MORRISON, C. F. (Tobacco Rsch. Council Labs., Harrogate, England), \& STEPHENSON, J. A. Drug effects on unconditioned light-avoidance in the rat. Psychopharmacologia (Berlin), 1972, 24, 456-461.

\section{Cannibis}

BUENO, O. F. A. (Setor de Psicofarmacologia, Departamento de Bioquímica e Farmacologia, Escola Paulista de Medicina, Săo Paulo, Brazil), \& CARLINI, E. A. Dissociation of learning in marihuana tolerant rats. Psychopharmacologia (Berlin), 1972, 25, 49-56.

CARDER, B. (Univ. of California, Los Angeles, Calif. 90024), \& OLSON, J. Marihuana and shock induced aggression in rats. Physiology \& Behavior, 1972, 8, 599602.

ELSMORE, T. F. (Dept. of Exptl. Psychol., Walter Reed Army Inst. of Rsch., Washington, D.C. 20012), \& F L E T C H E R, G . V $\Delta$-Tetrahydrocannabinol: Aversive effects in rat at high doses. Science, 1972, 175, 911-912.

M A S U R, J . ( S e t or d e Psicofarmacologia, Departamento de Bioquímica e Farmacologia, Escola Paulista de Medicina, Sāo Paulo, Brazil), MARTZ, R. M. W., \& CARLIII, E. A. The behavior of worker and non-worker rats under the influence of $(-) \Delta^{9}$-trans-tetrahydrocannabinol, chlorpromazine a n d a m y o b a r b itone. Psychopharmacologia (Berlin), $1972,25,57-68$.

PRADHAN, S. N. (Howard Univ. Coll. of Med., Washington, D.C. 20001), BAILEY, P. T., \& GHOSH, P. Effects of $\Delta^{9}$-tetrahydrocannabinol on a timing behavior in rats. Psychonomic Science, 1972, 27, 179-181.

\section{Stress Effects}

HERNER, D. (Vanderbilt Univ., Nashville, Tenn. 37203), \& CAUL, W. F. Restraint induced ulceration in rats during estrus and diestrus. Physiology \& Behavior, 1972, 8, 777-779.

KILPATRICK, D. G. (Dept. of Psychiat., Med. Univ. of South 
Carolina, Charleston, S.C. 29401). Differential responsiveness of two electrodermal indices to psychological stress and performance of a complex cognitive task. Psychophysiology, 1972, 9, 218-227.

MEYER, J. S. (Reg. Prim. Rsch. Ctr., Univ, of Wisconsin, Madison, Wis. 53706), \& BOWMAN, R. E. Rearing experience, stress and adrenocorticosteroids in the rhesus monkey. Physiology \& Behavior, 1972, 8, 339-343.

MIKHAIL, A. (Univ. of Manitoba, Winnipeg, Man., Canada), \& HIRSCHBERG, J. Ulceration in the rat's forestomach: Its reduction by non-nutritive bulky substances. Physiology \& Behavior, 1972, 8, 769-770.

PARÉ, W. P. (VA Hosp., Perry Point, Md. 21902). Conflict duration, feeding schedule, and strain differences in conflict-induced gastric ulcers. Physiology \& Behavior, 1972, 8, 165-171.

VAN-TOLLER, C. (Univ. of Durham, Durham, England), \& TARPY, $R$. $M$. Effect of cold stress on the performance of immunosympathectomized mice. Physiology \& Behavior, 1972, 8, 515-517.

\section{Autonomic Effects}

CAUL, W. F. (Vanderbilt Univ., Nashville, Tenn. 37203), BUCHANAN, D. C., \& HAYS, R. C. Effects of unpredictability of shock on incidence of gastric lesions and heart rate in immobilized rats. Physiology \& Behavior, 1972, 8, 669-672.

GAUTIER, H. (Laboratoire de physiologie, Faculté de Médecine Saint-Antoine, 27 rue Chaligny, Paris 12, France). Respiratory and heart rate responses to auditory stimulations. Physiology \& Behavior, 1972, 8, 327-332.

LYKKEN, D. T. (Psychiat. Rsch. Unit, Box 392 Mayo, Univ. of Minnesota, Minneapolis, Minn. 55455). Range correction applied to heart rate and to GSR data. Psychophysiology, $1972,9,373-379$

LYKKEN, D. T. (Psychiat. Rsch. Unit, Box 392 Mayo, Univ, of Minnesota, Minneapolis, Minn. 55455 ), MACINDOE, I., \& TELLEGEN, A. Preception: Autonomic response to shock as a function of predictability in t ime and locus. Psychophysiology, 1972,9 , 318-333.

PAPPAS, B. A. (Carleton Univ., Ottawa, Ont., Canada), DiCARA, L. V., \& MILLER, N. E. Acute s y m p a $t$ h e c t o m y b y 6-hydroxydopamine in the adult rat: Effects on cardiovascular conditioning and fear retention. Journal of Comparative \& Physiological Psychology, 1972, 79, 230-236.

\section{Heart Rate}

ADAMOWICZ, J. K. (Univ, of Western Ontario, London, Ont., Canada), \& GIBSON, D. Verbalization, cognitive effort, and heart rate alteration. Canadian Journal of Psychology, 1972, 26, 1-10.

AVIS, H. H. (Psychol. Sec., Biomed. Lab., Edgewood Arsenal, Md. 21010). Hippocampal injections of $\mathrm{KCl}$ and shock-induced bradycardia in the rat. Psychonomic Science, 1972, 27, 283-284

CAUL, W. F. (Vanderbilt Univ., Nashville, Tenn. 37203), \& BARRETT, R. J. Electroconvulsive shock effects on conditioned heart rate and suppression of drinking. Physiology \& Behavior, 1972, 8, 287-290

ELLIOTT, R. (Darmouth Coll., Hanover, N.H. 03755), \& GRAF, V. Visual sensitivity as a function of phase of cardiac cycle. Psychophysiology, 1972, 9, 357-361.

ENGEL, B. T. (Gerontol. Rsch. Ctr., Baltimore City Hosps., Baltimore, Md. 21224). Operant conditioning of cardiac function: A status report. Psychophysiology, $1972, \quad 9$, 161-177.

GALIN, D. (Langley Porter Neuropsychiat. Inst., 401 Parnassus Ave., San Francisco, Calif. 94122), \& LACEY, J. I. Reaction time and heart rate response pattern: Effects of reticular stimulation in cats. Physiology \& Behavior, 1972, 8 , 729-739.

HINE, B. (Dept. of Pharmacol. \& Toxicol., Purdue Univ., Lafayette, Ind. 47907), \& PAOLINO, R. M. Increases in heart rate accompanying decreases in activity and defecation: Support for a dual-process theory of habituation? Behavioral Biology, 1972, 7, 427-433.

OBRIST, P. A. (Dept. of Psychiat., Univ. of North Carolina Sch. of Med., Chapel Hill, N.C. 27514), HOWARD, J. L., LAWLER, J. E., SUTTERER, J. R., SMITHSON, K. W., \& MARTIN, P. L. Alterations in cardiac contractility during classical aversive conditioning in dogs: Methodological and theoretical implications. Psychophysiology, 1972, 9, 246-261.

SHAPIRO, D. (74 Fenwood Rd., Boston, Mass. 02115), SCHWARTZ, G. E., \& TURSKY, B. Control of diastolic blood pressure in man by feedback and reinforcement. Psychophysiology, 1972, 9, $296 \cdot 304$

SPENCE, D. P. (Rsch. Ctr. for Mental Health, New York Univ., New York, N.Y. 10003), LUGO, M., \& YOUDIN, $R$. Cardiac change as a function of attention to and awareness of continuous verbal text. Science, 1972, 176, 1.344-1346.

STEPHENS, J. H. (Henry Phipps Psychiat. Clin., Johns Hopkins Hosp., Baltimore, Md. 21205). Large magnitude heart rate changes in subjects instructed to change their heart rates and given exteroceptive feedback. Psychophysiology, 1972, 9, 283-285.

\section{Skin Conductance}

FUREDY, J. J. (Univ. of Toronto, Toronto 181, Ont., Canada). Electrodermal recovery time as a supra sensitive autonomic index of anticipated intensity of threatened shock. Psychophysiology, 1972, 9, 281-282.

KLINGE, V. (Lafayette Clin., $951 \mathrm{E}$. Lafayette, Detroit, Mich. 48207). Effects of exteroceptive feedback and instructions on control of spontaneous galvanic skin responses. Psychophysiology, 1972, 9, 305-317.

SHAPIRO, D. (Massachusetts Mental Health Ctr., 74 Fenwood Rd. Boston, Mass. 02115 ), \& WATANABE, T. Reinforcement of spontaneous electrodermal activity: A cross-cultural study in Japan. Psychophysiology, 1972,9 , 340-344. 